1 Submitted, accepted and published by:

2 International Journal of Greenhouse Control 28 (2014) 168-179

3

4

\title{
5
}

\section{Performance of $\mathrm{Cu}$ - and Fe-based oxygen carriers in a}

\section{$500 \mathrm{~W}_{\text {th }}$ CLC unit for sour gas combustion with high}

\author{
$\mathrm{H}_{2} \mathrm{~S}$ content
}

\author{
L.F. de Diego ${ }^{\mathrm{a}, ~ *}$, F. García-Labiano ${ }^{\mathrm{a}}$, P. Gayán ${ }^{\mathrm{a}}$, A. Abad ${ }^{\mathrm{a}}$, \\ A. Cabello ${ }^{\text {a }}$ J. Adánez ${ }^{\text {a }}$ G. Sprachmann ${ }^{\text {b }}$ \\ a Instituto de Carboquímica (ICB-CSIC), Department of Energy and Environment, \\ Miguel Luesma Castán 4, Zaragoza 50018, SPAIN. \\ ${ }^{\mathrm{b}}$ Shell Global Solutions International BV. Amsterdam, The Netherlands.
}

* Corresponding author. Tel.: +34 976733 977. Fax: +34 976733 318. E-mail address:

1dediego@icb.csic.es (Luis Francisco de Diego Poza)

\section{Abstract}

Sour gas represents about $43 \%$ of the world's natural gas reserves. The sustainable use of this fossil fuel energy entails the application of $\mathrm{CO}_{2}$ Capture and Storage (CCS) technologies. The Chemical Looping Combustion (CLC) technology can join the exploitation of the energy potential of the sour gas and the $\mathrm{CO}_{2}$ capture process in a single step without the need of a sweetening pre-treatment unit. In this work, a total of 60 hours of continuous operation with sour gas and $\mathrm{H}_{2} \mathrm{~S}$ concentrations up to 15 vol. \% has been carried out in a $500 \mathrm{~W}_{\text {th }}$ CLC unit, from which 40 corresponded to a Cu-based oxygen carrier $(\mathrm{Cu} 14 \gamma \mathrm{Al})$ and 20 to a Fe-based 
material $(\mathrm{Fe} 20 \gamma \mathrm{Al})$. This is the first time that so high $\mathrm{H}_{2} \mathrm{~S}$ concentrations are present in a fuel to be burnt in a CLC process. The $\mathrm{Cu} 14 \gamma \mathrm{Al}$ oxygen carrier seems to be no recommendable for the combustion of sour gas because, although all the $\mathrm{H}_{2} \mathrm{~S}$ is burnt to $\mathrm{SO}_{2}$, copper sulfides were

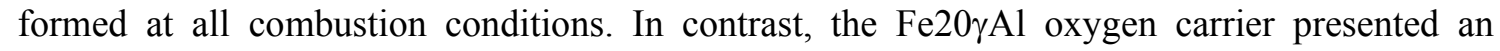
excellent behavior with no agglomeration problems and maintaining the reactivity of the fresh material. The sour gas $\left(\mathrm{CH}_{4}, \mathrm{H}_{2}\right.$, and $\left.\mathrm{H}_{2} \mathrm{~S}\right)$ was completely burnt, and neither $\mathrm{SO}_{2}$ was released in the AR nor iron sulfides were formed at usual CLC operating conditions. These tests demonstrated the possibility to use sour gas in a CLC process with $100 \% \mathrm{CO}_{2}$ capture without any $\mathrm{SO}_{2}$ emissions to the atmosphere.

Keywords. $\mathrm{CO}_{2}$ capture, Sour gas, Chemical Looping Combustion, oxygen carrier.

\section{Introduction}

Natural gas is a combustible mixture of hydrocarbon gases, being $\mathrm{CH}_{4}$ the most abundant compound, usually between 70 to 90 vol.\% . Other light hydrocarbons such as $\mathrm{C}_{2} \mathrm{H}_{6}, \mathrm{C}_{3} \mathrm{H}_{8}$ and $\mathrm{C}_{4} \mathrm{H}_{10}$ are present in the gaseous mixture in variable concentrations up to 20 vol.\%. This fuel gas is usually considered as sour gas if the $\mathrm{H}_{2} \mathrm{~S}$ content exceeds 5.7 milligrams of $\mathrm{H}_{2} \mathrm{~S}$ per cubic meter of natural gas (Katz et al., 1959), which is equivalent to approximately 4 ppm by volume under standard temperature and pressure. However, the composition of sour gas can vary widely depending on the extraction location, and wells with $\mathrm{H}_{2} \mathrm{~S}$ contents in the tens of percentage range are found (Hammer et al., 2006). According to Lallemand et al. (2012) a typical sour gas would contain about 10 vol. $\% \mathrm{H}_{2} \mathrm{~S}$, and high-sour and super-sour gases are considered those fuels with $\mathrm{H}_{2} \mathrm{~S}$ contents $\approx 20$ vol.\% and $>30$ vol.\%, respectively. Sour gas also contains significant amounts of other acid gas such as $\mathrm{CO}_{2}$ that can reach contents higher than 10 vol.\%.

The presence of $\mathrm{H}_{2} \mathrm{~S}$ in natural gas poses Health and Safety Environmental (HSE) problems due to the high toxicity of $\mathrm{H}_{2} \mathrm{~S}$ which makes necessary special operating procedures to ensure 
worker safety during drilling and in production operations. Furthermore, the presence of $\mathrm{H}_{2} \mathrm{~S}$ and $\mathrm{CO}_{2}$ can affect negatively to the economic value of the gaseous fuel due to the additional costs required for special materials compatible with these corrosive compounds and for the natural gas sweeting unit necessary to remove them previous to commercialize the natural gas (Romano, 2007).

It is probed that the natural gas is continuously increasing its role in meeting the world energy demand. According to the International Energy Agency (IEA, 2013), about 43\% of the world's natural gas reserves are sour gas sources, which revealed the great relevance of this type of fuel in the present and future energy scenario. The exploiting of the energy potential of sour gas entails the application of $\mathrm{CO}_{2}$ Capture and Storage (CCS) technologies since the $\mathrm{CO}_{2}$ content in this fuel can be appreciable as it was previously mentioned. Globally, the proven and probable sour gas resources have an estimated potential of 4 trillion $\mathrm{m}^{3}$ of net natural gas and $15000 \mathrm{Mt}$ of associated $\mathrm{CO}_{2}$ (Burgers et al., 2011).

Direct combustion of sour gas with a high $\mathrm{H}_{2} \mathrm{~S}$ content produces a high $\mathrm{SO}_{2}$ concentration in the flue gas. The separation of $\mathrm{SO}_{2}$ from the other components of the flue gas implies significant costs due to the large volumes of gas to be treated, making this option economically not viable. Thus, $\mathrm{H}_{2} \mathrm{~S}$ should be removed from sour gas previously to its combustion. Usually, the process of $\mathrm{H}_{2} \mathrm{~S}$ removal from natural gas, i.e., the sweetening process, is usually performed by an amine gas treatment process (Maddox, 1974). The waste gas stream obtained from the sweetening process is commonly known as acid gas.

Because the removal of $\mathrm{H}_{2} \mathrm{~S}$ from natural gas requires additional expenses concerning extra units for acid gas enrichment, other novel technologies such as the Controlled Freeze Zone ${ }^{\mathrm{TM}}$ (CFZ) gas treatment technology (Parker et al., 2011) or Chemical Looping Combustion (CLC) have emerged in the last years as potential single step separation processes of $\mathrm{CO}_{2}, \mathrm{H}_{2} \mathrm{~S}$ and other contaminants from a sour gas stream without the use of sorbents or absorbents.

The Chemical Looping Combustion technology would join the exploiting of the energy potential of the sour gas and the $\mathrm{CO}_{2}$ capture process in a single step. Figure 1 shows the technology train to deal with sour gases through CLC. 
CLC is a combustion technology based on the transfer of oxygen from air to fuel by means of a solid oxygen carrier which is continuously circulating between two interconnected fluidized bed reactors, the air reactor (AR) and the fuel reactor (FR) (Adánez et al., 2012). When a carbonaceous fuel is considered to be burnt, in a first step the fuel is oxidized in the FR to $\mathrm{CO}_{2}$ and $\mathrm{H}_{2} \mathrm{O}$ by a metal oxide $\left(\mathrm{Me}_{\mathrm{x}} \mathrm{O}_{\mathrm{y}}\right)$ which is reduced to a metal $(\mathrm{Me})$ or reduced form $\left(\mathrm{Me}_{\mathrm{x}} \mathrm{O}_{\mathrm{y}-1}\right)$. A highly concentrated stream of $\mathrm{CO}_{2}$ is obtained after water condensation and purification. In a second step, the metal or reduced metal oxide is oxidized with air in the AR regenerating the material for a new cycle.

The objective in a CLC process that uses sour gas as fuel is to generate a highly concentrated stream of $\mathrm{CO}_{2}$ and $\mathrm{SO}_{2}$ in the $\mathrm{FR}$, avoiding as much as possible the release of sulfur in the $\mathrm{AR}$ stream. The $\mathrm{SO}_{2}$ produced in the FR can be separated at a lower cost since the volumetric flow of the flue gases is seven times less than by means of direct combustion in the burner-boiler, resulting in significantly smaller post-treatment units. Shell Global Solutions International BV company has developed a patent (Mirfenderski and Sprachmann, 2013) where sour gas is used as fuel for thermal energy conversion without the need of a sweetening pre-treatment utilizing the high caloric content of burning $\mathrm{H}_{2} \mathrm{~S}$, with improved capture of the produce $\mathrm{SO}_{2}$, whilst maintaining the $\mathrm{CO}_{2}$ inherent separation characteristics of CLC. The captured $\mathrm{SO}_{2}$ may be sent to a next destination such as e.g. a sulfuric acid plant, a sulfur recovery plant, liquid $\mathrm{SO}_{2}$, or even injection of the $\mathrm{CO}_{2} / \mathrm{SO}_{2}$ mixture. carriers in a $500 \mathrm{~W}_{\text {th }}$ continuous CLC unit regarding the presence of $\mathrm{H}_{2} \mathrm{~S}$ in the gaseous fuel. These oxygen carriers were based on Ni (García-Labiano et al., 2009), Mn (Cabello et al., 2014b), Fe (Cabello et al., 2014a) and $\mathrm{Cu}$ (Forero et al., 2010) oxides. The material based on nickel oxide was not suitable to be used for the CLC process with $\mathrm{H}_{2} \mathrm{~S}$-containing fuels, at concentrations higher than $100 \mathrm{vppm}$, since deactivation of the oxygen carrier took place at all 
operating conditions by $\mathrm{Ni}_{3} \mathrm{~S}_{2}$ formation. Regarding the Mn-based oxygen carrier, in the form of a perovskite $\left(\mathrm{CaMn}_{0.9} \mathrm{Mg}_{0.1} \mathrm{O}_{3-\delta}\right)$, the addition of $\mathrm{H}_{2} \mathrm{~S}$ caused a negative effect on its behavior for the CLC process in terms of agglomeration problems, deactivation and loss of oxygen uncoupling capacity. Thermodynamic analyses conclude that manganese sulfides are not found as predominant sulfur species during the interaction of Mn-based oxygen carriers with sulfur (Jerndal et al., 2006; Wang et al., 2005). The poisoning of this perovskite by $\mathrm{H}_{2} \mathrm{~S}$ addition was not due to the presence of manganese oxide within its structure, but due to the presence of $\mathrm{Ca}$ that could form certain undesired compounds such as $\mathrm{CaSO}_{4}$ and $\mathrm{CaS}$. Fe- and $\mathrm{Cu}$-based oxygen carriers presented a good CLC performance using fuels containing $\mathrm{H}_{2} \mathrm{~S}$ (Cabello et al., 2014a; Forero et al., 2010). In the case of the Fe-based oxygen carrier, the presence of $\mathrm{H}_{2} \mathrm{~S}$ in the fuel gas did not affect the behavior of the material independently of the amount of sulfur present in the fuel stream. Iron sulfides were not formed, the redox reactivity was maintained during operation and high combustion efficiencies were obtained with and without sulfur presence. Regarding the $\mathrm{Cu}$-based oxygen carrier, the presence of $\mathrm{H}_{2} \mathrm{~S}$ did not produce the deactivation of the material working at oxygen carrier-to-fuel ratios, $\phi$, above 1.5. At these conditions, complete combustion of fuel was achieved and the great majority of the sulfur fed into the system ( $\approx 95$ vol. $\%$ ) was released in the gas outlet stream of the FR as $\mathrm{SO}_{2}$. For $\phi$ values lower than 1.5 , the formation of copper sulfide, $\mathrm{Cu}_{2} \mathrm{~S}$, was detected, and the oxygen carrier was deactivated. However, this material was completely regenerated in a $\mathrm{H}_{2} \mathrm{~S}-$ free atmosphere.

It must be remarked that the maximum $\mathrm{H}_{2} \mathrm{~S}$ content in all the above works was $3400 \mathrm{vppm}$. However, the amount of $\mathrm{H}_{2} \mathrm{~S}$ in sour gas sources can be very elevated, being increased several orders of magnitude (Katz et al., 1959). As above mentioned, the composition of sour gas can vary widely depending on the extraction location, and wells with $\mathrm{H}_{2} \mathrm{~S}$ contents in the tens of percentage range can be found (Hammer et al., 2006; Lallemand et al., 2012). The presence of sulfur in the fuel can affect to the quality of the concentrated $\mathrm{CO}_{2}$ stream obtained or to the admissible emission of pollutants if it is released as $\mathrm{SO}_{2}$ in the $\mathrm{FR}$ or $\mathrm{AR}$, respectively. In 
addition, the possible poisoning of the oxygen carrier by sulfur becomes crucial when using sour gas as fuel because metal sulfides formation decreases the oxygen carrier reactivity, oxygen transport capacity and fuel conversion potential.

Based on previous experience, the objective of this work was to analyze the behavior of two materials based on $\mathrm{Cu}$ and $\mathrm{Fe}$, respectively, during sour gas combustion in a $500 \mathrm{~W}_{\text {th }}$ CLC unit in presence of high $\mathrm{H}_{2} \mathrm{~S}$ concentrations, up to 15 vol. \%. The influence of $\mathrm{H}_{2} \mathrm{~S}$ concentration on the gas products distribution, sulfur splitting between FR and AR and oxygen carrier deactivation were investigated. Furthermore, the evolution of the main oxygen carrier properties during the time of operation was also analyzed.

\section{Experimental section}

\subsection{Oxygen carrier materials}

$\mathrm{A} \mathrm{Cu}$ - and a Fe-based oxygen carriers were prepared at ICB-CSIC by the incipient impregnation method using $\gamma-\mathrm{Al}_{2} \mathrm{O}_{3}$ as support. These materials were designated as $\mathrm{Cu} 14 \gamma \mathrm{Al}$ and $\mathrm{Fe} 20 \gamma \mathrm{Al}$ oxygen carrier respectively. The $\mathrm{CuO}$ content in the $\mathrm{Cu} 14 \gamma \mathrm{Al}$ oxygen carrier particles was 14.2 wt.\%, whereas the $\mathrm{Fe}_{2} \mathrm{O}_{3}$ content in the $\mathrm{Fe} 20 \gamma \mathrm{Al}$ material was 20.4 wt.\%. The corresponding oxygen transport capacities, $\mathrm{R}_{\mathrm{OC}}$, were 2.9 and $2.0 \%$, respectively. The method of preparation and the main physical and chemical properties of both materials were deeply explained by Adánez et al. (2006) and Gayán et al. (2012).

\subsection{ICB-CSIC-g1 facility}

Sour gas combustion tests were carried out in the ICB-CSIC-g1 facility $\left(500 \mathrm{~W}_{\text {th }}\right)$. Figure 2 shows a schematic diagram of the unit after the modifications made for safe operation with high $\mathrm{H}_{2} \mathrm{~S}$ concentrations. The atmospheric chemical-looping combustor prototype was composed of two interconnected fluidized-bed reactors, the air reactor and the fuel reactor, separated by a loop seal, a riser for solids transport to the fuel reactor, a cyclone and a solid valve to control the solids fed to the fuel reactor. An important feature of the prototype was the possibility to control and measure the solids circulation rate at any moment through the solids valves located above 
the FR. Moreover, the prototype allowed the collection of solid material samples from the AR or the FR at any moment for further characterization. A detailed description of the installation can be found elsewhere (García-Labiano et al., 2009; Forero et al., 2010).

The CLC unit was modified by including three mass flow controllers for $\mathrm{H}_{2} \mathrm{~S}, \mathrm{H}_{2}$ and $\mathrm{H}_{2} \mathrm{O}$. The synthetic sour gas was fed at the bottom of the reactor. This made necessary the use of a special distributor plate manufactured in Kanthal APM. $\mathrm{H}_{2}$ was also added to avoid $\mathrm{H}_{2} \mathrm{~S}$ decomposition in the feeding line. Furthermore, to avoid corrosion problems with reactor alloys some steam was also included in the feeding gas stream. Two scrubbers containing a saturated solution of sodium carbonate were located in the gas outlet streams of the FR and AR reactors to keep the emissions below the Health, Safety and the Environment (HSE) limits. Furthermore, a special installation for gas leakage detection was included in the CLC unit. This security system is composed by three gas detectors, a control unit and two electronic valves. Two gas detectors (one for $\mathrm{H}_{2} \mathrm{~S}$ and another one for $\mathrm{SO}_{2}$ ) were located inside the cupboard covering the CLC plant, and an additional $\mathrm{H}_{2} \mathrm{~S}$ gas detector was installed outside near the plant. The gas detectors were configured for 5 vppm alarm. All the detectors were connected to the control unit. If a gas leakage was detected, several alarms were switched on and the relays of the control unit acted on the electronic valves. In such case, the $\mathrm{H}_{2} \mathrm{~S}$ flow was closed and the line was flushed with $\mathrm{N}_{2}$. Some specific analyzers for sulfur compounds were placed at the outlet streams of the AR and FR. A non-dispersive infrared (NDIR) analyzer (Siemens Ultramat U22) was used to detect the $\mathrm{SO}_{2}$ concentration obtained at the AR gas outlet stream. Different solutions were used for online gas concentration determination downstream the FR: a) a NDIR analyzer to measure the $\mathrm{SO}_{2}$ concentration, and b) a gas chromatograph (Varian 3400-CX GC) equipped with a PORAPAK-Q packed column and a sulfur-specific Flame Photometric Detector (FPD) for the $\mathrm{SO}_{2}$ determination at low concentrations, and with a Thermal Conductivity Detector (TCD) for $\mathrm{SO}_{2}$ concentrations above 1 vol.\%. In this way, it was also possible the detection of the different gaseous sulfur compounds that can appear in the FR such as $\mathrm{H}_{2} \mathrm{~S}, \mathrm{SO}_{2}, \mathrm{COS}, \mathrm{CS}_{2}$, etc. The chromatograph was calibrated in the range 0-2000 vppm for $\mathrm{H}_{2} \mathrm{~S}$ and $0-20$ vol. $\%$ for $\mathrm{SO}_{2}$. It must be remarked that only the $\mathrm{SO}_{2}$ concentration data corresponding to the NDIR analyzer will 
be showed in Section 3 of this paper. Furthermore, the sulfur mass balances that appear in

Sections 3.1.3 and 3.2.3 were carried out considering the aforementioned data.

\subsection{Testing conditions}

The total solids inventory in the system was the same for both oxygen carriers, $1.2 \mathrm{~kg}$ approximately, of which 0.3 and $0.5 \mathrm{~kg}$ were in the FR and AR, respectively. A total operation time of 60 hours of continuous operation with sour gas and different $\mathrm{H}_{2} \mathrm{~S}$ concentrations up to 15 vol. \% were carried out in the $500 \mathrm{~W}_{\text {th }}$ CLC unit, from which 40 hours corresponded to the Cu-based oxygen carrier and 20 hours to the Fe-based material. The temperatures used in the CLC unit were different for the sour gas combustion tests depending on the oxygen carrier used. In the case of the $\mathrm{Cu} 14-\gamma \mathrm{Al}$ material, the temperatures in the FR and AR were $1073 \mathrm{~K}$ and 1123 $\mathrm{K}$ respectively. On the other hand, the Fe-based oxygen carrier was subjected to higher temperatures: $1173 \mathrm{~K}$ in the FR and $1223 \mathrm{~K}$ in the AR. The gas flows fed to the reactors were identical for all sour gas combustion tests. The inlet gas flow in the FR was $191 \mathrm{~L}_{\mathrm{N}} / \mathrm{h}(0.1 \mathrm{~m} / \mathrm{s}$ at $1173 \mathrm{~K})$. The AR was fluidized with air, which was divided into the primary air, added from the bottom bed $\left(720 \mathrm{~L}_{\mathrm{N}} / \mathrm{h}\right)$, and the secondary air, added at the top of the bubbling bed to help particle entrainment in the riser $\left(150 \mathrm{~L}_{\mathrm{N}} / \mathrm{h}\right)$. Nitrogen was also used to fluidize the bottom loop $\operatorname{seal}\left(37.5 \mathrm{~L}_{\mathrm{N}} / \mathrm{h}\right)$.

Tables 1 and 2 shows a summary of the main variables used in the sour combustion tests carried out with the $\mathrm{Cu}$-based and Fe-based materials respectively. The oxygen carrier-to-fuel ratio, $\phi$, which was defined as the ratio between the oxygen supplied and the oxygen needed to stoichiometrically react with the fuel flow, was calculated by Eq. (1) as follows:

$213 \phi=\frac{F_{\mathrm{MeO}}}{b \cdot F_{\text {Fuel }}}$

where $\mathrm{F}_{\mathrm{MeO}}$ is the molar flow rate of the metal oxide. $\mathrm{F}_{\mathrm{MeO}}$ can be calculated considering both the solid flow rate (measured by means of a diverting solids valve located below the cyclone, see Figure 2) and the metal oxide content of the oxygen carrier. $F_{\text {Fuel }}$ is the inlet molar flow rate of the fuel in the FR. The parameter $b$ is the stoichiometric coefficient of the fuel gas and depends on the oxygen carrier used during combustion tests (Cu-based or Fe-based oxygen 
carrier) and on the fuels present in the sour gas composition $\left(\mathrm{CH}_{4}, \mathrm{H}_{2} \mathrm{~S}\right.$, and $\left.\mathrm{H}_{2}\right)$. This parameter

220 was determined as a function of the solids circulation rate, $\mathrm{f}_{\mathrm{s}}$. A value of $\phi=1$ corresponds to

221 the stoichiometric $\mathrm{MeO}$ amount needed for complete conversion of the sour gas to $\mathrm{CO}_{2}, \mathrm{SO}_{2}$,

222 and $\mathrm{H}_{2} \mathrm{O}$.

223 Regarding the combustion tests conducted with the $\mathrm{Cu} 14-\gamma \mathrm{Al}$ material, test $\mathrm{Cu} 1$ corresponded to

224 the reference test carried out without $\mathrm{H}_{2} \mathrm{~S}$ addition. Tests $\mathrm{Cu} 2-\mathrm{Cu} 4$ were performed the first days

225 of operation with sulfur addition. During these tests, the $\mathrm{H}_{2} \mathrm{~S}$ concentration was low, reaching

226 values up to 3 vol. \%. Tests $\mathrm{Cu} 5-\mathrm{Cu} 6, \mathrm{Cu} 7-\mathrm{Cu} 9$ and $\mathrm{Cu} 10-\mathrm{Cu} 12$ corresponded to $\mathrm{H}_{2} \mathrm{~S}$

227 concentrations of 5,10 and 15 vol. \%, respectively. For each $\mathrm{H}_{2} \mathrm{~S}$ concentration tested in the

228 CLC unit, several $\mathrm{CH}_{4}$ contents were used. The variation of concentration of both compounds

229 allowed us to check the behavior of the oxygen carrier under different oxygen carrier-to-fuel

230 ratios. At the end of the experimentation, a total of 40 hours of continuous operation with $\mathrm{H}_{2} \mathrm{~S}$

231 feeding was reached.

232 Finally, test $\mathrm{Cu} 13$ was carried out with a new batch of oxygen carrier particles selecting the same operating conditions as in test $\mathrm{Cu} 5$, but replacing $\mathrm{N}_{2}$ for $\mathrm{CO}_{2}$ as gas balance. This atmosphere would better represent the atmosphere existing in a FR where only fuel is added. It must be remarked that the CLC unit of ICB-CSIC is limited by the AR design up to $500 \mathrm{~W}_{\text {th }}$. This fact makes necessary to use some gas as balance that it is introduced together with the fuel. In the case of the Fe-based oxygen carrier, most of the tests were carried out using $\mathrm{CO}_{2}$ as diluting agent. Tests Fe1-Fe4 corresponded to experiments with 10 vol. $\% \mathrm{CH}_{4}, 5$ vol. $\% \mathrm{H}_{2}$ and increasing amounts of $\mathrm{H}_{2} \mathrm{~S}$ from 0 up to 15 vol.\%. Tests Fe5-Fe8 were carried out at a higher $\mathrm{CH}_{4}$ content (20 vol.\%) and increasing amounts of $\mathrm{H}_{2} \mathrm{~S}$ (up to 15 vol.\%). It must be remarked that in tests $\mathrm{Fe} 7$ and $\mathrm{Fe} 8$ the $\phi$ value was very low. After that, it was decided to repeat test $\mathrm{Fe} 6$

242 in order to check if repetitive results were obtained. Finally, tests Fe10 and Fe11 were 243 performed at the same operating conditions as in tests $\mathrm{Fe} 6$ and $\mathrm{Fe} 1$, but replacing the $\mathrm{CO}_{2}$ gas 244 balance by $\mathrm{N}_{2}$. These last tests were carried out to check again if the variation of gas affected to 
245 the obtained results. At the end, 20 hours of continuous operation were performed with the

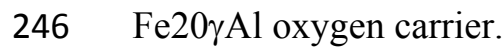
determine the fate of sulfur when $\mathrm{Cu}$-based oxygen carriers are used in a CLC plant with sour above 1, complete combustion of fuel gas to $\mathrm{CO}_{2}, \mathrm{H}_{2} \mathrm{O}$ and $\mathrm{SO}_{2}$ was achieved (see Equations 2 $-5)$. The unique stable sulfur compound at these conditions was $\mathrm{SO}_{2}$. If the oxygen carrier-to-

\subsection{Tests of sour gas combustion with the Cu14- $\gamma \mathrm{Al}$ oxygen carrier}

\subsubsection{Thermodynamic calculations for copper materials}

A thermodynamic study was carried out using the HSC Chemistry 6.1 (2008) software to gas. This program obtains the equilibrium composition by using the method of minimization of the Gibbs free energy of the system for a fixed mass balance, at constant pressure and temperature.

The calculations were performed considering $\mathrm{CuO}$ as oxygen carrier and typical sour gas compositions. Figure 3 shows the thermodynamic equilibrium of the compounds existing in the FR for two sour gas compositions, (sour gas 1: 99.5 vol. $\% \mathrm{CH}_{4}-0.5$ vol. $\% \mathrm{H}_{2} \mathrm{~S}$, and sour gas 2: 85 vol. $\% \mathrm{CH}_{4}-15$ vol. $\% \mathrm{H}_{2} \mathrm{~S}$ ) as a function of the oxygen carrier-to-fuel ratio, $\phi$, and at $1073 \mathrm{~K}$. The reactions considered between the fuel $\left(\mathrm{CH}_{4}+\mathrm{H}_{2} \mathrm{~S}\right)$ and the active phase of the oxygen carrier are the following depending on the value of parameter $\phi$ :

$$
8 \mathrm{CuO}+\mathrm{CH}_{4} \Leftrightarrow 4 \mathrm{Cu}_{2} \mathrm{O}+\mathrm{CO}_{2}+2 \mathrm{H}_{2} \mathrm{O} \quad(\phi>2)
$$

$$
4 \mathrm{Cu}_{2} \mathrm{O}+\mathrm{CH}_{4} \Leftrightarrow 8 \mathrm{Cu}+\mathrm{CO}_{2}+2 \mathrm{H}_{2} \mathrm{O} \quad(2>\phi>1)
$$

$6 \mathrm{CuO}+\mathrm{H}_{2} \mathrm{~S} \Leftrightarrow 3 \mathrm{Cu}_{2} \mathrm{O}+\mathrm{SO}_{2}+\mathrm{H}_{2} \mathrm{O}$

$$
(\phi>2)
$$

$$
3 \mathrm{Cu}_{2} \mathrm{O}+\mathrm{H}_{2} \mathrm{~S} \Leftrightarrow 6 \mathrm{Cu}+\mathrm{SO}_{2}+\mathrm{H}_{2} \mathrm{O} \quad(2>\phi>1)
$$

The values obtained from the thermodynamic analysis were expressed as the volumetric percentage of gas product composition for sour gas combustion and as the molar percentage of sulfur species present in the products in relation to the sulfur fed into the system. At $\phi$ values fuel ratio decreased below 1, unreacted $\mathrm{H}_{2}$ and $\mathrm{CO}$ appeared and reached a maximum when $\mathrm{H}_{2} \mathrm{O}$ 
and $\mathrm{CO}_{2}$ concentrations are zero. Below that point, $\mathrm{CH}_{4}$ appeared as an unreacted gas. Moreover, different solid and gaseous sulfur species, mainly $\mathrm{Cu}_{2} \mathrm{~S}$ and $\mathrm{H}_{2} \mathrm{~S}$, appeared at substoichiometric conditions as a function the oxygen present in the system. The concentration of $\mathrm{H}_{2} \mathrm{~S}$ and $\mathrm{Cu}_{2} \mathrm{~S}$ in equilibrium depended on the $\mathrm{H}_{2}$ concentration through reaction (6):

$2 \mathrm{Cu}+\mathrm{H}_{2} \mathrm{~S} \Leftrightarrow \mathrm{Cu}_{2} \mathrm{~S}+\mathrm{H}_{2}$

It can be observed that the amount of $\mathrm{Cu}_{2} \mathrm{~S}$ in equilibrium increased with the $\mathrm{H}_{2} \mathrm{~S}$ content in the sour gas. Thermodynamic calculations made at different temperatures from 973 to $1273 \mathrm{~K}$ showed similar results.

The above results were obtained considering $\mathrm{CuO}$ as the only active copper-based specie present in the oxygen carrier particles. However, XRD characterization showed that $\mathrm{Cu} 14-\gamma \mathrm{Al}$ material was composed by $\mathrm{CuO}$ and a spinel-structure $\mathrm{CuAl}_{2} \mathrm{O}_{4}$ due to the interaction between the active phase $(\mathrm{CuO})$ and support $\left(\gamma-\mathrm{Al}_{2} \mathrm{O}_{3}\right)$ (Adánez et al., 2006). The distribution between $\mathrm{CuO}$ and $\mathrm{CuAl}_{2} \mathrm{O}_{4}$ in the oxygen carrier depends on several factors but the presence of $\mathrm{CuAl}_{2} \mathrm{O}_{4}$ can be as high as $75 \%$ during usual operation. Experience on previous works carried out at ICB-CSIC indicated that both compounds were able to react with fuel gases, i.e., the spinel phase was also reducible by the fuel gas (de Diego et al., 2004, 2005, 2007).

The reduction reactions that take place in the FR between $\mathrm{CuAl}_{2} \mathrm{O}_{4}$ and the combustible fraction of sour gas are the following:

$8 \mathrm{CuAl}_{2} \mathrm{O}_{4}+\mathrm{CH}_{4} \Leftrightarrow 8 \mathrm{CuAlO}_{2}+4 \mathrm{Al}_{2} \mathrm{O}_{3}+\mathrm{CO}_{2}+2 \mathrm{H}_{2} \mathrm{O}$

$$
(\phi>2)
$$

$8 \mathrm{CuAlO}_{2}+\mathrm{CH}_{4} \Leftrightarrow 8 \mathrm{Cu}+4 \mathrm{Al}_{2} \mathrm{O}_{3}+\mathrm{CO}_{2}+2 \mathrm{H}_{2} \mathrm{O}$

$$
(2>\phi>1)
$$

$$
6 \mathrm{CuAl}_{2} \mathrm{O}_{4}+\mathrm{H}_{2} \mathrm{~S} \Leftrightarrow 6 \mathrm{CuAlO}_{2}+3 \mathrm{Al}_{2} \mathrm{O}_{3}+\mathrm{SO}_{2}+\mathrm{H}_{2} \mathrm{O}
$$$$
(\phi>2)
$$

$$
6 \mathrm{CuAlO}_{2}+\mathrm{H}_{2} \mathrm{~S} \Leftrightarrow 6 \mathrm{Cu}+3 \mathrm{Al}_{2} \mathrm{O}_{3}+\mathrm{SO}_{2}+\mathrm{H}_{2} \mathrm{O}
$$$$
(2>\phi>1)
$$

The oxidation in the AR happens through reactions (11) and (12):

$$
2 \mathrm{Cu}+1 / 2 \mathrm{O}_{2}+\mathrm{Al}_{2} \mathrm{O}_{3} \Leftrightarrow 2 \mathrm{CuAlO}_{2}
$$

$2 \mathrm{CuAlO}_{2}+1 / 2 \mathrm{O}_{2}+\mathrm{Al}_{2} \mathrm{O}_{3} \Leftrightarrow 2 \mathrm{CuAl}_{2} \mathrm{O}_{4}$

The same thermodynamic calculations as in the previous case with $\mathrm{CuO}$ were performed considering $\mathrm{CuAl}_{2} \mathrm{O}_{4}$ as oxygen carrier. In this case $\mathrm{CuAl}_{2} \mathrm{O}_{4}$ data given from Jacob and Alcock 
(1975) were used to carry out the thermodynamic analyses. The obtained results were identical

with both $\mathrm{Cu}$-based compounds, $\mathrm{CuO}$ and $\mathrm{CuAl}_{2} \mathrm{O}_{4}$, as it can be observed in Figure 3 .

\subsubsection{Combustion tests in the ICB-CSIC-g1 facility}

To evaluate the suitability of the $\mathrm{Cu} 14-\gamma \mathrm{Al}$ material for sour gas combustion, some experimental tests were performed in the $500 \mathrm{~W}_{\text {th }}$ CLC unit. The combustion efficiency, the sulfur splitting between reactors, and the reactivity of fresh and after-used particles were analyzed for each experiment.

In test $\mathrm{Cu}$, without $\mathrm{H}_{2} \mathrm{~S}$ addition, full combustion of $\mathrm{CH}_{4}$ to $\mathrm{CO}_{2}$ and $\mathrm{H}_{2} \mathrm{O}$ was obtained. This is the usual behavior of this Cu-based material at the operating conditions used here. The absence of carbon formation in the oxygen carrier particles was maintained during the whole experimentation.

During the first 2 hours of operation with sulfur addition (3000 vppm) in test $\mathrm{Cu} 2$, no $\mathrm{SO}_{2}$ was detected at the outlet gas stream of the FR or AR. After that, almost all the sulfur fed to the installation was detected as $\mathrm{SO}_{2}$ at the gas outlet stream from the FR.

During tests $\mathrm{Cu} 3$ and $\mathrm{Cu} 4, \mathrm{CH}_{4}$ was fully burnt to $\mathrm{CO}_{2}$ and $\mathrm{H}_{2} \mathrm{O} . \mathrm{CO}, \mathrm{H}_{2}$, and $\mathrm{H}_{2} \mathrm{~S}$ were never detected in the FR stream. The latter compound was mainly transformed into $\mathrm{SO}_{2}$ through reactions (4), (5), (9) and (10). In addition, variable amounts of $\mathrm{SO}_{2}$ (up to 300-400 vppm) were found at the outlet of the AR.

During tests $\mathrm{Cu} 5$ and $\mathrm{Cu} 6$, with a sulfur content of 5 vol.\% $\mathrm{H}_{2} \mathrm{~S}$ in the feeding gas, the $\mathrm{SO}_{2}$ concentration at the outlet gas stream from the FR was maintained quite constant during all the operation time with values close to the sulfur fed. However, the amounts of $\mathrm{SO}_{2}$ detected at the outlet of the AR increased, reaching values up to $2000 \mathrm{vppm}\left(5720 \mathrm{mg} / \mathrm{Nm}^{3}\right)$ in test Cu5. In test $\mathrm{Cu} 6, \mathrm{CH}_{4}$ concentration was decreased, which corresponded to an increase in the value of the parameter $\phi$. The response to this change in the gas product distribution was very quick in both reactors, with slightly increasing the $\mathrm{SO}_{2}$ concentration in the $\mathrm{FR}$ and decreasing in the $\mathrm{AR}$ up to values of $100-200 \mathrm{ppm}\left(286-572 \mathrm{mg} / \mathrm{Nm}^{3}\right)$. To corroborate if this change could be attributed 
previous values were again reached. This fact demonstrated a relation between the oxygen

327

328

329

330

331

332

333

334

335

carrier-to-fuel ratio and the $\mathrm{SO}_{2}$ concentration obtained at the outlet of the $\mathrm{AR}$, in such a way that the $\mathrm{SO}_{2}$ concentration was higher as lower was the $\phi$ value. A similar behavior was found when the solids circulation rate was varied.

A possible explanation to this phenomenon may be that some $\mathrm{Cu}_{2} \mathrm{~S}$ was formed inside the FR through reaction (6), being favored when more metallic copper was present in this reactor, that is, when the circulation rate or the $\phi$ value were lower. The $\mathrm{Cu}_{2} \mathrm{~S}$ transported to the AR could be partially burnt to $\mathrm{SO}_{2}$ according to reaction (13):

$\mathrm{Cu}_{2} \mathrm{~S}+2 \mathrm{O}_{2} \Leftrightarrow 2 \mathrm{CuO}+\mathrm{SO}_{2}$

As an example of the sour gas combustion tests, Figure 4 shows the gas composition obtained at the outlet of the FR and AR for the tests $\mathrm{Cu} 7-\mathrm{Cu} 9$ corresponding to 10 vol.\% $\mathrm{H}_{2} \mathrm{~S}$ in the gas feeding. It was observed the same relation between parameter $\phi$ and the $\mathrm{SO}_{2}$ concentration obtained at the outlet of the $\mathrm{AR}$ as in tests $\mathrm{Cu} 5$ and $\mathrm{Cu} 6$, i.e., the $\mathrm{SO}_{2}$ concentration was higher as lower was the value of the parameter $\phi$. Again, it was possible that some $\mathrm{Cu}_{2} \mathrm{~S}$ could be formed in the lower zone of the fluidized bed, which was partially released in the $\mathrm{AR}$ as $\mathrm{SO}_{2}$ and some was being accumulated in the particles.

In the lower part of Figure 4 a graph showing the instantaneous sulfur mass balance was added. This mass balance, expressed as mol of sulfur per hour, includes the sulfur fed to the system, the sulfur detected at the outlet of the FR and AR, and the total sulfur in the gas phase leaving both reactors. The difference between the sulfur fed and the total sulfur detected in the gas phase at the exit of the FR and AR could be due to experimental errors or to formation of copper sulfides in the oxygen carrier particles.

In the experimental tests $\mathrm{Cu} 10-\mathrm{Cu} 12$ performed with the highest concentration of $\mathrm{H}_{2} \mathrm{~S}$, i.e., 15 vol.\%, it was found again the same relation between the $\mathrm{SO}_{2}$ released in the $\mathrm{AR}$ and the parameter $\phi$. However, these tests showed the lowest emissions of sulfur in the gas phase among all the tests, which indicated that there were more sulfides formed or more experimental errors in the measurements. It must be considered that tests $\mathrm{Cu} 10-\mathrm{Cu} 12$ correspond to the most 
extreme conditions, with the highest $\mathrm{H}_{2} \mathrm{~S}$ concentration, and when the particles have already been subjected to almost 40 hours of continuous operation with some sulfur accumulated inside the particles, as it will be showed later (see Section 3.1.4). Nevertheless, agglomeration was never detected in the CLC unit using this oxygen carrier. The presence of sulfur inside the particles did not alter their properties regarding agglomeration because they were prepared under the guidelines proposed by de Diego et al. (2005) to avoid this problem in copper-based oxygen carriers.

After test $\mathrm{Cu} 12$, the whole solids inventory was replaced by a new batch of particles and an additional test, test $\mathrm{Cu} 13$, was carried out at the same operating conditions as in test $\mathrm{Cu} 5$ but using $\mathrm{CO}_{2}$ instead of $\mathrm{N}_{2}$ as gas balance. This test was performed to analyze the effect of the reacting atmosphere on the behavior of the oxygen carrier during sour gas combustion. The results obtained in terms of gas product distribution and sulfur mass balance were similar to the obtained in test $\mathrm{Cu} 5$ which indicated that the gas balance atmosphere had a negligible effect on the material performance.

\subsubsection{Sulfur mass balance}

A sulfur mass balance was performed to the different tests carried out in the CLC unit with the Cu14yAl material. Sulfur splitting between reactors and the possible formation of copper sulfides in the oxygen carrier particles were analyzed. Figure 5 shows this balance in terms of percentage of sulfur released in both FR and AR. It can be observed that most of the sulfur appeared as $\mathrm{SO}_{2}$ in the $\mathrm{FR}$, and a minor part (less than $13 \mathrm{wt} . \%$ ) in the AR. It can be also noticed that there was an amount of sulfur that was not detected in the gas phase. This amount was high in some tests, which cannot be only attributed to experimental errors. It was concluded that some sulfur was accumulated in the oxygen carrier, as it will be demonstrated in the next characterization section. It must be remarked the behavior of the material during the first experiment with sulfur addition (test $\mathrm{Cu} 2$ ), where there was an important accumulation of sulfur inside the oxygen carrier particles since only a $23 \%$ of the sulfur fed was released as $\mathrm{SO}_{2}$ in the FR. Also, it is remarkable the results obtained in tests $\mathrm{Cu} 10-12$ which presented the lowest sulfur emissions in the gas phase, both in FR and AR. These tests correspond to the most 
extreme conditions, with the highest $\mathrm{H}_{2} \mathrm{~S}$ concentration, and after 35 hours of continuous operation.

According to the thermodynamic data showed in section 3.1.1, and considering that the tests were always carried out at $\phi$ values above 1 , no copper sulfides should be formed at any of the operating conditions used during the experimental work. However, it is necessary to take into consideration that inside the FR fluidized bed could be a reducing zone with possible high CO and $\mathrm{H}_{2}$ concentrations and considerable presence of metallic copper that could be responsible of the copper sulfides formation (Forero et al., 2010), see reaction (6). To confirm this possibility, a solid characterization to samples extracted from the system at different times was carried out.

\subsubsection{Characterization of the oxygen carrier}

Samples of Cu14 $\gamma \mathrm{Al}$ material were extracted from the FR and AR at the end of each experimental test for solid characterization. Table 3 shows the main characteristics of those samples.

XRD characterization showed the main compounds existing in the samples extracted from the AR. The equipment used was a X-ray diffractometer Bruker AXS D8 Advance with BraggBrentano geometry configuration, $\mathrm{Cu} \mathrm{K} \alpha$ radiation and equipped with secondary graphite monochromator. Different crystalline species, such as $\mathrm{Al}_{2} \mathrm{O}_{3}, \mathrm{CuAl}_{2} \mathrm{O}_{4}$ and $\mathrm{CuO}$, were detected. Regarding stable sulfur phases, no copper sulfides were detected in any case. However, it is reasonable to think that the amounts of copper sulfides were below the detection limit of the apparatus (5 wt.\%). To check the presence of sulfur in the oxygen carrier particles at lower amounts, the samples were analyzed by ultimate analysis in a Thermo Flash 1112 . From this characterization technique, important amounts of sulfur were detected, which are showed in Table 3. Considering $\mathrm{Cu}_{2} \mathrm{~S}$ as the unique copper sulfide possible at the experimental conditions used in the tests, the content of this compound in the samples was calculated. It seems that the $\mathrm{Cu}_{2} \mathrm{~S}$ content depends on the operation conditions and it can be concluded that sulfur was being accumulated along time in the oxygen carrier particles during the sour gas combustion tests.

The presence of sulfur inside the particles was also detected by SEM-EDX. The equipment used was a scanning electron microscope (SEM) ISI DS-130 coupled to an ultra-thin window PGT 

section of an oxygen carrier particle after $40 \mathrm{~h}$ of sour gas combustion inside the CLC prototype. It can be observed that a significant presence of sulfur was detected in those areas where metallic copper was accumulated.

Finally, the reactivity of the oxygen carrier particles along the time of operation was determined in a TGA CI Electronics type, described elsewhere (Abad et al, 2011), using $\mathrm{CH}_{4}$ as reducing gas. It was observed in Figure 7 that samples lost some oxygen transport capacity and reactivity. Nevertheless, the reactivity until $40 \%$ of solid conversion was maintained high. In this point it must be highlight that the $\phi$ values used in the CLC unit were in the range from 1.3 to 3.7 , corresponding to variations of solid conversion below 0.6 in most of the experiments. By this reason, a decrease in the $\mathrm{CH}_{4}$ conversion along time was not noticed during combustion tests. However, it is expected that reactivity decreases below acceptable values for long operating times as the existing in CLC units at industrial scale. The $\mathrm{SO}_{2}$ concentrations at the outlet of the AR corresponded to values measured at the operating conditions used in the tests. When these values were normalized to an excess of 6 vol. $\% \mathrm{O}_{2}$, the $\mathrm{SO}_{2}$ emissions were always higher than $200 \mathrm{mg} / \mathrm{Nm}^{3}$, the EU emissions limit for boilers higher than $200 \mathrm{MW}_{\mathrm{th}}$. Considering the above data and the confirmed accumulation of sulfur in the oxygen carrier particles as $\mathrm{Cu}_{2} \mathrm{~S}$, the use of Cu-based oxygen carriers for sour gas combustion with high $\mathrm{H}_{2} \mathrm{~S}$ concentrations is not recommended.

3.2 Tests of sour gas combustion with the Fe20 $\gamma \mathrm{Al}$ oxygen carrier

\subsubsection{Thermodynamic calculations for iron materials}

430 Similar calculations to the previously ones were performed for Fe-based materials.

431 Thermodynamic calculations of different sour gas compositions were carried out in a range of 432 temperature from $1073 \mathrm{~K}$ to $1373 \mathrm{~K}$. Figure 8a shows the thermodynamic equilibrium existing 433 at $1223 \mathrm{~K}$, for a sour gas composed by 85 vol. $\% \mathrm{CH}_{4}$ and $15 \mathrm{vol} . \% \mathrm{H}_{2} \mathrm{~S}$, as a function of the oxygen carrier-to-fuel ratio, $\phi$, when the redox pair considered is $\mathrm{Fe}_{2} \mathrm{O}_{3}-\mathrm{Fe}_{3} \mathrm{O}_{4}$. In this case, a 
value of $\phi=1$ corresponds to the stoichiometric amount of $\mathrm{Fe}_{2} \mathrm{O}_{3}$ needed for a full conversion of the fuel $\left(\mathrm{CH}_{4}+\mathrm{H}_{2} \mathrm{~S}\right)$ to $\mathrm{CO}_{2}, \mathrm{SO}_{2}$, and $\mathrm{H}_{2} \mathrm{O}$ through reactions (14) and (15).

$$
12 \mathrm{Fe}_{2} \mathrm{O}_{3}+\mathrm{CH}_{4} \Leftrightarrow 8 \mathrm{Fe}_{3} \mathrm{O}_{4}+\mathrm{CO}_{2}+2 \mathrm{H}_{2} \mathrm{O}
$$

$9 \mathrm{Fe}_{2} \mathrm{O}_{3}+\mathrm{H}_{2} \mathrm{~S} \Leftrightarrow 6 \mathrm{Fe}_{3} \mathrm{O}_{4}+\mathrm{SO}_{2}+\mathrm{H}_{2} \mathrm{O}$

Thermodynamic results are expressed as the volumetric percentage of gas composition and as the molar percentage of sulfur species present in the products in relation to the sulfur fed into the system. Furthermore, Figure $8 \mathrm{a}$ includes the different iron species in equilibrium at the different $\phi$ values considered. At $\phi$ values above 1, complete combustion of the fuel gas mixture to $\mathrm{CO}_{2}, \mathrm{H}_{2} \mathrm{O}$, and $\mathrm{SO}_{2}$ was achieved. Again, the unique stable sulfur compound working with Fe-based oxygen carriers was $\mathrm{SO}_{2}$, similarly to the case with the $\mathrm{Cu}$-based oxygen carrier. At sub-stoichiometric conditions, $\mathrm{CO}_{2}$ and $\mathrm{H}_{2} \mathrm{O}$ concentrations decreased as the amount of oxygen provided by the active Fe-based specie was reduced. On the contrary, $\mathrm{H}_{2}$ and $\mathrm{CO}$ concentrations progressively increased reaching their maximum values when the iron oxide was fully reduced to metallic iron. Finally, at very low $\phi$ values, lower than 0.1 , unreacted $\mathrm{CH}_{4}$ appeared in the equilibrium while the amounts of $\mathrm{CO}$ and $\mathrm{H}_{2}$ dramatically decreased. Different solid and gaseous sulfur species can appear at $\phi$ values below 1 depending on the oxygen available in the system. The main iron sulfide present was the $\mathrm{Fe}_{0.877} \mathrm{~S}$ and always appeared some $\mathrm{H}_{2} \mathrm{~S}$ in equilibrium. Small amounts of $S_{2}(g)$ were also found at $\phi$ values close to 1 .

However, a special case corresponds to Fe-based oxygen carriers prepared by impregnation on $\mathrm{Al}_{2} \mathrm{O}_{3}$. In this case, iron aluminate $\left(\mathrm{FeAl}_{2} \mathrm{O}_{4}\right)$ can be formed as reduced compound allowing complete combustion of gas to $\mathrm{CO}_{2}$ and $\mathrm{H}_{2} \mathrm{O}$ (Abad et al., 2007; Cabello et al., 2014a; Gayán et al., 2012; Leion et al., 2008), and increasing three times the oxygen transport capacity of the oxygen carrier in comparison with the redox pair $\mathrm{Fe}_{2} \mathrm{O}_{3}-\mathrm{Fe}_{3} \mathrm{O}_{4}$. Additional thermodynamic calculations including $\mathrm{Al}_{2} \mathrm{O}_{3}$ as solid phase were performed using the HSC Chemistry 6.1 program. Figure $8 \mathrm{~b}$ shows the results corresponding to sour gas containing 15 vol. $\% \mathrm{H}_{2} \mathrm{~S}$. In this case, a value of $\phi=1$ corresponds to the stoichiometric amount of $\mathrm{Fe}_{2} \mathrm{O}_{3}$, supported on $\mathrm{Al}_{2} \mathrm{O}_{3}$, 
needed for full conversion of the fuel $\left(\mathrm{CH}_{4}+\mathrm{H}_{2} \mathrm{~S}\right)$ to $\mathrm{CO}_{2}, \mathrm{SO}_{2}$ and $\mathrm{H}_{2} \mathrm{O}$ when the redox pair considered is $\mathrm{Fe}_{2} \mathrm{O}_{3}\left(\mathrm{Al}_{2} \mathrm{O}_{3}\right)-\mathrm{FeAl}_{2} \mathrm{O}_{4}$.

$4 \mathrm{Fe}_{2} \mathrm{O}_{3}+8 \mathrm{Al}_{2} \mathrm{O}_{3}+\mathrm{CH}_{4} \Leftrightarrow 8 \mathrm{FeAl}_{2} \mathrm{O}_{4}+\mathrm{CO}_{2}+2 \mathrm{H}_{2} \mathrm{O}$

465 The gas product distribution and the sulfur species at $\phi$ values higher than 1 were the same as in 466 the previous case when the redox pair $\mathrm{Fe}_{2} \mathrm{O}_{3}-\mathrm{Fe}_{3} \mathrm{O}_{4}$ was considered: full combustion of fuel gas 467 to $\mathrm{CO}_{2}, \mathrm{H}_{2} \mathrm{O}$, and $\mathrm{SO}_{2}$ as the unique sulfur compound present in the system. At substoichiometric conditions, unreacted $\mathrm{H}_{2}$ and $\mathrm{CO}$ appeared reaching their maximum values when the equilibrium $\mathrm{Fe}-\mathrm{FeAl}_{2} \mathrm{O}_{4}$ was found. In this case, $\mathrm{CO}_{2}$ and $\mathrm{H}_{2} \mathrm{O}$ were not present in the gas equilibrium. $\mathrm{CH}_{4}$ appeared as an unreacted gas at very low $\phi$ values when hematite was fully reduced to metallic iron. Interesting results were obtained at sub-stoichiometric conditions regarding sulfur species present in the reaction products. In this case, formation of iron sulfides were only possible at very low values of $\phi(\phi<0.4)$, with most of the sulfur appearing as $\mathrm{H}_{2} \mathrm{~S}$.

474 This can be considered as a remarkable result and even more if we consider that the transformation $\mathrm{Fe}_{2} \mathrm{O}_{3}\left(\mathrm{Al}_{2} \mathrm{O}_{3}\right)-\mathrm{FeAl}_{2} \mathrm{O}_{4}$ supposes to increase three times the oxygen transport capacity with respect to the use of the pair $\mathrm{Fe}_{2} \mathrm{O}_{3}-\mathrm{Fe}_{3} \mathrm{O}_{4}$. Thermodynamic calculations made at temperatures from 1073 to $1373 \mathrm{~K}$ and sour gas with different $\mathrm{H}_{2} \mathrm{~S}$ contents showed similar results.

\subsubsection{Combustion tests in the ICB-CSIC-g1 facility}

The behavior of the Fe-based oxygen carrier in sour gas atmospheres with high $\mathrm{H}_{2} \mathrm{~S}$ concentrations was analyzed in the ICB-CSIC-g1 facility under continuous operating conditions. Table 2 shows the combustion tests carried out and the experimental conditions used.

During tests $\mathrm{Fe} 1-\mathrm{Fe} 4$, with a $\mathrm{CH}_{4}$ concentration of 10 vol.\%, neither $\mathrm{CO}$ nor $\mathrm{H}_{2}$ was detected in the gas outlet stream from FR and full combustion of $\mathrm{CH}_{4}$ to $\mathrm{CO}_{2}$ and $\mathrm{H}_{2} \mathrm{O}$ was obtained with $100 \%$ of carbon capture. Reactions (16) and (18) were considered to take place in the FR: 
In addition, neither $\mathrm{CO}$ nor $\mathrm{CO}_{2}$ was detected in the $\mathrm{AR}$ in any of the tests, which means that no carbon was ever formed during fuel combustion in the FR. In the AR, the oxidation of the material took place through reaction (19):

$8 \mathrm{FeAl}_{2} \mathrm{O}_{4}+2 \mathrm{O}_{2} \Leftrightarrow 4 \mathrm{Fe}_{2} \mathrm{O}_{3}+8 \mathrm{Al}_{2} \mathrm{O}_{3}$

492

Taking into account the results of previous works (Cabello et al., 2014, Gayán et al., 2012), this is the usual behavior of this Fe-based material at the operating conditions used when no $\mathrm{H}_{2} \mathrm{~S}$ was fed into the combustor.

Regarding the combustion of the $\mathrm{H}_{2} \mathrm{~S}$ fed to the CLC system during tests $\mathrm{Fe} 2-\mathrm{Fe} 4$, it must be remarked the very good behavior obtained with this oxygen carrier. All the $\mathrm{H}_{2} \mathrm{~S}$ was burnt by the oxygen carrier through reaction (17) and the $\mathrm{SO}_{2}$ concentration obtained at the outlet of the FR was very close to the one corresponding to full combustion of $\mathrm{H}_{2} \mathrm{~S}$. No $\mathrm{SO}_{2}$ was released in the AR in any of the operating conditions.

500 Due to the excellent results obtained in tests $\mathrm{Fe} 1-4$, the $\mathrm{CH}_{4}$ concentration was increased up to 20 vol.\% in tests $\mathrm{Fe} 5-\mathrm{Fe} 9$ to analyze the oxygen carrier behavior when the parameter $\phi$ took lower values (see Table 2). The results obtained in these tests are showed in Figure 9. Test Fe5 corresponded to the reference test without $\mathrm{H}_{2} \mathrm{~S}$ addition and $\mathrm{CH}_{4}$ concentration of 20 vol.\%. In this case, the combustion of $\mathrm{CH}_{4}$ was almost complete because a very small amount of unreacted $\mathrm{CH}_{4}\left(<0.8\right.$ vol.\%) appeared at the outlet stream from the FR. Furthermore, neither $\mathrm{H}_{2}$ of $\mathrm{CH}_{4}$ to $\mathrm{CO}_{2}$ and $\mathrm{H}_{2} \mathrm{O}$ was achieved in the FR. However, an increase in the $\mathrm{H}_{2} \mathrm{~S}$ concentration up to 15 vol.\% (test $\mathrm{Fe} 8$ ) produced a decrease in the percentage of $\mathrm{SO}_{2}$ obtained in the $\mathrm{FR}$ in relation to the $\mathrm{H}_{2} \mathrm{~S}$ fed. Furthermore, some unconverted $\mathrm{CH}_{4}$ appeared in the FR and increasing amounts of $\mathrm{SO}_{2}$ appeared in the AR. This last fact could be as a consequence of the iron sulfides

511 formed in the FR through reaction (20) that could be burnt in the AR according to reaction (21)

512 due to the low $\phi$ values (1.5 and 1.3, respectively) used in these tests.

$513 \quad \mathrm{FeO} \cdot \mathrm{Al}_{2} \mathrm{O}_{3}+\mathrm{H}_{2} \mathrm{~S} \Leftrightarrow \mathrm{FeS}+\mathrm{Al}_{2} \mathrm{O}_{3}+\mathrm{H}_{2} \mathrm{O}$

$5142 \mathrm{FeS}+7 / 2 \mathrm{O}_{2} \Leftrightarrow \mathrm{Fe}_{2} \mathrm{O}_{3}+2 \mathrm{SO}_{2}$ 
515 As it was mentioned in Section 3.2.1, thermodynamic calculations showed that $\mathrm{Fe}_{0.877} \mathrm{~S}$ was the 516 only stable sulfide that could be formed at $\phi$ values lower than 0.4 , through the reaction (20).

517 Nevertheless, in order to facilitate the adjustment of the chemical reactions, FeS has been 518 considered as the stable iron sulfide instead of the $\mathrm{Fe}_{0.877} \mathrm{~S}$ compound.

519 Comparing the $\phi$ values needed to boost thermodynamically the formation of iron sulfides with 520 the ones used in the CLC plant during the experimental campaign, it could be concluded that 521 iron sulfides should be not formed in any case at usual operating conditions.

522 After that, conditions corresponding to test Fe6 were reestablished in test $\mathrm{Fe} 9$ to evaluate if iron sulfides were reversible when the amount of oxygen available for combustion increased. In this case, $\mathrm{CH}_{4}$ concentration at the outlet of the FR decreased, i.e., the combustion behavior of the oxygen carrier particles was improved, and more sulfur, in the form of $\mathrm{SO}_{2}$, was detected at the outlet of the FR in relation to the amount fed into the CLC system. These results indicated that the possible iron sulfides formed at reducing conditions were reversible and no accumulation in the particles was produced. The regeneration of the iron sulfides would be carried out in the FR by the reverse of reaction (20), that is, by reaction of the iron sulfide with the steam existing in the environment. The amount of $\mathrm{H}_{2} \mathrm{~S}$ produced would be further burnt by normal reaction with the oxygen carrier to release $\mathrm{SO}_{2}$, see reaction (17).

532 The conclusion obtained after these tests revealed that the CLC unit must be operated at $\phi$ 533 values higher than 1.5 to obtain full combustion of $\mathrm{H}_{2} \mathrm{~S}$ to $\mathrm{SO}_{2}$ in the $\mathrm{FR}$, and therefore to avoid 534 iron sulfides formation and $\mathrm{SO}_{2}$ emissions at the AR outlet stream.

535 Finally, in tests $\mathrm{Fe} 10$ and $\mathrm{Fe} 11$ the $\mathrm{CO}_{2}$ used as balance in the previous tests was replaced by $536 \mathrm{~N}_{2}$. The results obtained during test Fe10 indicated that the gas atmosphere had no influence over the combustion process and sulfur distribution behavior. Test Fe11 was performed without $\mathrm{H}_{2} \mathrm{~S}$ feeding in a $\mathrm{N}_{2}$ atmosphere to check if the oxygen carrier particles maintained their 539 reactivity after iron sulfides formed during test Fe8 and later regeneration. The results obtained 540 during this new reference test were very satisfactory considering that almost full $\mathrm{CH}_{4}$ 541 combustion was again achieved. 
543 With the above experimental data, a sulfur mass balance was carried out to the different sour 544 gas combustion tests. Figure 10 shows this balance expressed in terms of molar percentage of 545 sulfur considering the amounts released as $\mathrm{SO}_{2}$ both in the FR and in the AR. It can be observed that in tests $\mathrm{Fe} 2-\mathrm{Fe} 4$ and $\mathrm{Fe} 6-\mathrm{Fe} 7$, all the sulfur detected appeared as $\mathrm{SO}_{2}$ in the $\mathrm{FR}$, and the mass balances closed within $8 \%$ of deviation. This deviation could be due to experimental errors or to some sulfur accumulation in the oxygen carrier particles as iron sulfides. Only in test $\mathrm{Fe} 8$, corresponding to a very low oxygen-carrier-to fuel ratio $(\phi=1.3)$, some $\mathrm{SO}_{2}$ was detected in the AR. Furthermore, during this test the total amount of sulfur detected in the gas phase was lower than in the previous tests. This result would indicate a zone of operating conditions which favored the formation of iron sulfides. Finally, in tests $\mathrm{Fe} 9$ and Fe10, more amount than the corresponding to the sulfur fed was obtained at the outlet of the FR, which indicated the regeneration of the oxygen carrier by the disappearance of the iron sulfides formed.

\subsubsection{Characterization of the oxygen carrier}

557 Different samples of the Fe20 $\gamma \mathrm{Al}$ oxygen carrier were extracted from the FR and AR during the 20 hours of continuous operation for further solid characterization. Table 4 shows the main characteristics of those samples.

Powder XRD patterns showed the main crystalline phases existing in the fresh and used samples extracted from the AR at different times of operation. The fresh material was composed by $\mathrm{Fe}_{2} \mathrm{O}_{3}$ and $\alpha-\mathrm{Al}_{2} \mathrm{O}_{3}$, and this structure was maintained along operation. Iron sulfides were not detected in any case, which could be due to the detection limit of the apparatus. To evaluate the presence of sulfur inside the samples, used particles were subjected to ultimate analyses with a Thermo Flash 1112 analyzer. Sulfur was only detected in the samples extracted after test Fe8 where only the 76 wt.\% of the sulfur fed was released in the gas phase, and some $\mathrm{SO}_{2}$ was detected in the AR. Nevertheless, the amount of sulfur was very low. No sulfur was found in the samples of subsequent tests, which meant that the iron sulfides formed had disappeared and the material was completely regenerated. 
571 techniques. Figure 11 shows a SEM image of the cross-section of oxygen carrier particles 572 extracted from the CLC unit after test Fe8. The SEM-EDX analysis revealed a small amount of 573 sulfur in the material.

574 Finally, thermogravimetric experiments were performed to fresh and after-used particles in

\section{Conclusions}

A total of 60 hours of continuous operation with sour gas and different $\mathrm{H}_{2} \mathrm{~S}$ concentrations up to 15 vol. \% has been carried out in the ICB-CSIC-g1 facility $\left(500 \mathrm{~W}_{\text {th }}\right)$, from which 40 corresponded to a $\mathrm{Cu}$-based oxygen carrier and 20 hours to a Fe-based material.

During the sour gas combustion tests with the $\mathrm{Cu} 14 \gamma \mathrm{Al}$ material, stable operation was achieved with no agglomeration problems. This oxygen carrier was able to burn completely a synthetic sour gas. Sulfur was mainly released as $\mathrm{SO}_{2}$ in the $\mathrm{FR}$, although some amounts were also released in the AR. As a general rule, the $\mathrm{SO}_{2}$ concentration in the $\mathrm{AR}$ decreased as higher was the oxygen carrier-to-fuel ratio, $\phi$. Nevertheless, with the operating conditions selected during this experimental work it was not possible to reach in this reactor $\mathrm{SO}_{2}$ emissions lower than 200 $\mathrm{mg} / \mathrm{Nm}^{3}$, the EU limit of emissions for boilers higher than $200 \mathrm{MW}_{\text {th }}$. Furthermore, $\mathrm{Cu}_{2} \mathrm{~S}$ was formed at all operating conditions, being accumulated during operation. Therefore, it was concluded that $\mathrm{Cu}$-based oxygen carriers were not adequate for sour gas combustion in a CLC process.

On the contrary, the behavior of the Fe-based oxygen carrier during the sour gas combustion tests was very satisfactory. The Fe $20 \gamma \mathrm{Al}$ material was able to burn completely the sour gas at usual oxygen-carrier-to fuel ratios. The high reactivity of the fresh material was maintained 
597 throughout all the operation time even in the presence of high $\mathrm{H}_{2} \mathrm{~S}$ concentrations. Furthermore, 598 neither $\mathrm{SO}_{2}$ was released in the AR nor iron sulfides were formed at oxygen carrier-to-fuel 599 ratios higher than 1.5. Therefore, it is concluded that this Fe-based material is very adequate for 600 the combustion of sour gas, even with high $\mathrm{H}_{2} \mathrm{~S}$ content, allowing $\mathrm{CO}_{2}$ capture without any $\mathrm{SO}_{2}$ 601 emissions to the atmosphere.

602

603

604

605 Acknowledgements

606 This work has been financed by Shell Global Solutions International B.V. within the frame of 607 the agreement PT22648 signed between Shell Global Solutions International B.V. and Instituto 608 de Carboquímica - Consejo Superior de Investigaciones Científicas (ICB -CSIC).

609 


\section{References}

611

612

613

614

615

616

617

618

619

620

621

622

623

624

625

626

627

628

629

630

631

632

633

634

635

636

637

Abad, A., García-Labiano, F., de Diego, L.F., Gayán, P., Adánez, J., 2007. Reduction kinetics of $\mathrm{Cu}-$, Ni- and Fe-based oxygen carriers using syngas $\left(\mathrm{CO}+\mathrm{H}_{2}\right)$ for chemical looping combustion. Energy \& Fuels. 21, 1843-1853.

Abad, A., Adánez, J., Cuadrat, A., García-Labiano, F., Gayán, P., de Diego, L.F., 2011. Kinetics of redox reactions of ilmenite for chemical-looping combustion. Chem. Eng. Sci. 66, 689701.

Adánez, J., Gayán, P., Celaya, J., de Diego, L.F., García-Labiano, F., Abad, A., 2006. Chemical-looping combustion in a $10 \mathrm{~kW}$ prototype using a $\mathrm{CuO} / \mathrm{Al}_{2} \mathrm{O}_{3}$ oxygen carrier: effect of operating conditions on methane combustion. Ind. Eng. Chem. Res. 45, 60756080.

Adánez, J., Abad, A., García - Labiano, F., Gayán, P., de Diego, L.F., 2012. Progress in Chemical Looping Combustion and Reforming Technologies. Progress in Energy and Combustion Science. 38, 215-282.

Burgers, W.F.J., Northrop, P.S., Kheshgi, H.S., Valencia, J.A., 2011. Worldwide development potential for sour gas. Energy Procedia. 4, 2178-2184.

Cabello, A., Dueso, C., García-Labiano, F., Gayán, P., Abad, A., de Diego, L.F., Adánez, J. 2014a. Performance of a highly reactive impregnated $\mathrm{Fe}_{2} \mathrm{O}_{3} / \mathrm{Al}_{2} \mathrm{O}_{3}$ oxygen carrier with $\mathrm{CH}_{4}$ and $\mathrm{H}_{2} \mathrm{~S}$ in a $500 \mathrm{~W}_{\text {th }}$ CLC unit. Fuel. 121, 117-125.

Cabello, A., Abad, A., Gayán, P., de Diego, L.F., García-Labiano, F., Adánez, J., 2014b. Effect of operating conditions and $\mathrm{H}_{2} \mathrm{~S}$ presence on performance of $\mathrm{CaMg}_{0.1} \mathrm{Mn}_{0.9} \mathrm{O}_{3-\delta}$ perovskite material in CLC. Energy \& Fuels. 28, 1262-1274.

de Diego, L.F., García-Labiano, F., Adánez, J., Gayán, P., Abad, A., Corbella, B.M., Palacios, J.M., 2004. Development of Cu-based oxygen carriers for chemical-looping combustion. Fuel. 83, 1749-1757.

de Diego, L.F., Gayán, P., García-Labiano, F., Celaya, J., Abad, A., Adánez, J., 2005. Impregnated $\mathrm{CuO} / \mathrm{Al}_{2} \mathrm{O}_{3}$ oxygen carriers for chemical-looping combustion: avoiding fluidized bed agglomeration. Energy \& Fuels. 19, 1850-1856. 
de Diego, L.F., García-Labiano, F., Gayán, P., Celaya, J., Palacios, J.M., Adánez, J., 2007. Operation of a $10 \mathrm{~kW}_{\text {th }}$ chemical-looping combustor during $200 \mathrm{~h}$ with a $\mathrm{CuO}-\mathrm{Al}_{2} \mathrm{O}_{3}$ oxygen carrier. Fuel. 86, 1036-1045.

Forero, C.R., Gayán, P., García-Labiano, F., de Diego, L.F., Abad, A., Adánez, J. 2010. Effect of gas composition in chemical-looping combustion with copper-based oxygen carriers: Fate of sulphur. Int J Greenhouse Gas Control. 4, 762-770.

García-Labiano, F., de Diego, L.F., Gayán, P., Adánez, J., Abad, A., Dueso, C. 2009. Effect of fuel gas composition in chemical-looping combustion with Ni-based oxygen carriers. 1. Fate of sulphur. Ind Eng Chem Res. 48, 2499-2508.

Gayán, P., Pans, M.A., Ortiz, M., Abad, A., de Diego, L.F., García-Labiano, F., Adánez, J., 2012. Testing of a highly reactive impregnated $\mathrm{Fe}_{2} \mathrm{O}_{3} / \mathrm{Al}_{2} \mathrm{O}_{3}$ oxygen carrier for a SR-CLC system in a continuous CLC unit. Fuel Processing Technology. 96, 37-47.

Hammer, G., Lübcke, T., Kettner, R., Pillarella, M.R., Recknagel, H., Commichau, A., Neumann, H.J., Paczynska-Lahme, B., 2006. Natural Gas. Ullmann's Encyclopedia of Industrial Chemistry. Wiley-VCH, Weinheim.

HSC Chemistry 6.1., 2008. Chemical Reaction and Equilibrium Software with Thermochemical Database and Simulation Module. Oututec Research Oy, Pori, Finland.

IEA, 2013. International Energy Agency. World Energy Outlook 2013.

Jacob, KT., Alcock, C.B., 1975. Thermodynamics of $\mathrm{CuAlO}_{2}$ and $\mathrm{CuAl}_{2} \mathrm{O}_{4}$ and Phase equilibria in the system $\mathrm{Cu}_{2} \mathrm{O}-\mathrm{CuO}-\mathrm{Al}_{2} \mathrm{O}_{3}$. J Am. Ceram. Soc. 58, 192-195.

Jerndal, E., Mattisson, T., Lyngfelt, A., 2006. Thermal analysis of chemical-looping combustion. Chem. Eng Res Des. 84, 795-806.

Katz, D.L., Cornell, D., Vary, J.A., Kobayasi, R., Elenbaas, J.R., Poettmann, F.H., Weinaug, C.F., 1959. Handbook of Natural Gas Engineering, McGraw-Hill Book Company, New York.

Lallemand, F., Perdu, G., Maretto, C., Weiss, C., Magne-Drisch, J., Lucquin, A.C, 2012. Solutions for the treatment of highly sour gases. Process technologies for the cost-effective 
665

666

667

668

669

670

671

672

673

674

675

676

677

678

679

680

681

682

683

treatment of natural gas with high and ultra-high acid gas content. Digital Refining. www.digitalrefining.com/article/1000356.

Leion, H., Lyngfelt, A., Johansson, M., Jerndal, E., Mattisson, T., 2008. The use of ilmenite as an oxygen carrier in chemical-looping combustion. Chem. Eng Res Des. 86, 1017-1026.

Maddox, R.N., 1974. Gas and Liquid Sweetening, 2nd ed. Campbell Petroleum Series, Norman, OK.

Mirfenderski, Y., Sprachmann G., 2013. Chemical-looping combustion of sour gas. Patent 2610216.

Parker, M.E., Northrop, S., Valencia, J.A., Foglesong, R.E., Duncan, W.T., 2011. $\mathrm{CO}_{2}$ Management at ExxonMobil's Labarge Field, Wyoming, USA. Energy Procedia. 4, 54555470 .

Romano, U., 2007. Encyclopaedia of hydrocarbons. Volume III. New developments: energy, transport, sustainability. Istituto della enciclopedia italiana Fondata da Giovanni Treccani S.p.a.

Wang, B., Yan, R., Lee, D.H., Liang, D.T., Zheng, Y., Zhao, H., Zheng, C., 2005. Thermodynamic investigation of carbon deposition and sulphur evolution in chemical looping combustion with syngas. Energy \& Fuels. 22, 1012-1020. 
685 Figure 1. Scheme to deal with sour gases through Chemical Looping Combustion technology.

686 Figure 2. Scheme of the ICB-CSIC-g1 facility $\left(500 \mathrm{~W}_{\text {th }}\right)$ after modifications made for safe 687 operation with high $\mathrm{H}_{2} \mathrm{~S}$ concentrations.

Figure 3. Thermodynamic calculations for the systems $\mathrm{CuO} /$ sour gas and $\mathrm{CuAl}_{2} \mathrm{O}_{4} / \mathrm{sour}$ gas. Sour gas 1 composition: 85 vol. $\% \mathrm{CH}_{4}-15$ vol. $\% \mathrm{H}_{2} \mathrm{~S}$. Sour gas 2 composition: 99.5 vol. $\% \mathrm{CH}_{4^{-}}$ 0.5 vol. $\% \mathrm{H}_{2} \mathrm{~S} . \mathrm{T}=1073 \mathrm{~K}$.

691

Figure 4. Gas composition at the outlet stream from the FR and AR, and sulfur balance corresponding to tests $\mathrm{Cu} 7-9$ with the $\mathrm{Cu} 14 \gamma \mathrm{Al}$ material.

693

Figure 5. Sulfur mass balances for the combustion of sour gas with the Cu-based oxygen 694 carrier. Only gas emissions as $\mathrm{SO}_{2}$ in FR and $\mathrm{AR}$ are considered.

695

Figure 6. SEM-EDX image of a cross-section of a Cu14 $\gamma \mathrm{Al}$ oxygen carrier particle after $40 \mathrm{~h}$ of

696 sour gas combustion in the CLC unit.

697

698

Figure 7. Reduction reactivity of the $\mathrm{Cu} 14-\gamma \mathrm{Al}$ material after different combustion tests with sour gas. Reducing gas: 15 vol. $\% \mathrm{CH}_{4} . \mathrm{T}=1073 \mathrm{~K}$.

699

Figure 8. Thermodynamic calculations for the systems $\mathrm{Fe}_{2} \mathrm{O}_{3}-\mathrm{Fe}_{3} \mathrm{O}_{4} /$ sour gas (a) and $\mathrm{Fe}_{2} \mathrm{O}_{3}\left(\mathrm{Al}_{2} \mathrm{O}_{3}\right)-\mathrm{FeO} \cdot \mathrm{Al}_{2} \mathrm{O}_{3}$ /sour gas (b). Sour gas composition: 85 vol.\% $\mathrm{CH}_{4}-15$ vol.\% $\mathrm{H}_{2} \mathrm{~S}$. $\mathrm{T}=1223 \mathrm{~K}$

Figure 9. Gas composition at the outlet stream from the FR and AR, and sulfur balance corresponding to tests Fe5-9 with the Fe20 $\gamma \mathrm{Al}$ oxygen carrier.

Figure 10. Sulfur mass balances for the combustion of sour gas with the Fe-based oxygen carrier.

Figure 11. SEM-EDX image of a cross-section of a Fe20 $\gamma \mathrm{Al}$ oxygen carrier particle after test Fe8 in the CLC unit.

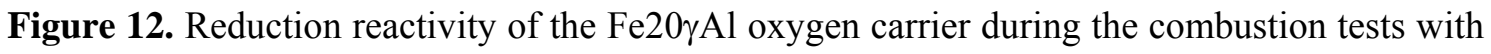
sour gas. Reducing gas: 15 vol. $\% \mathrm{CH}_{4} . \mathrm{T}=1223 \mathrm{~K}$. 


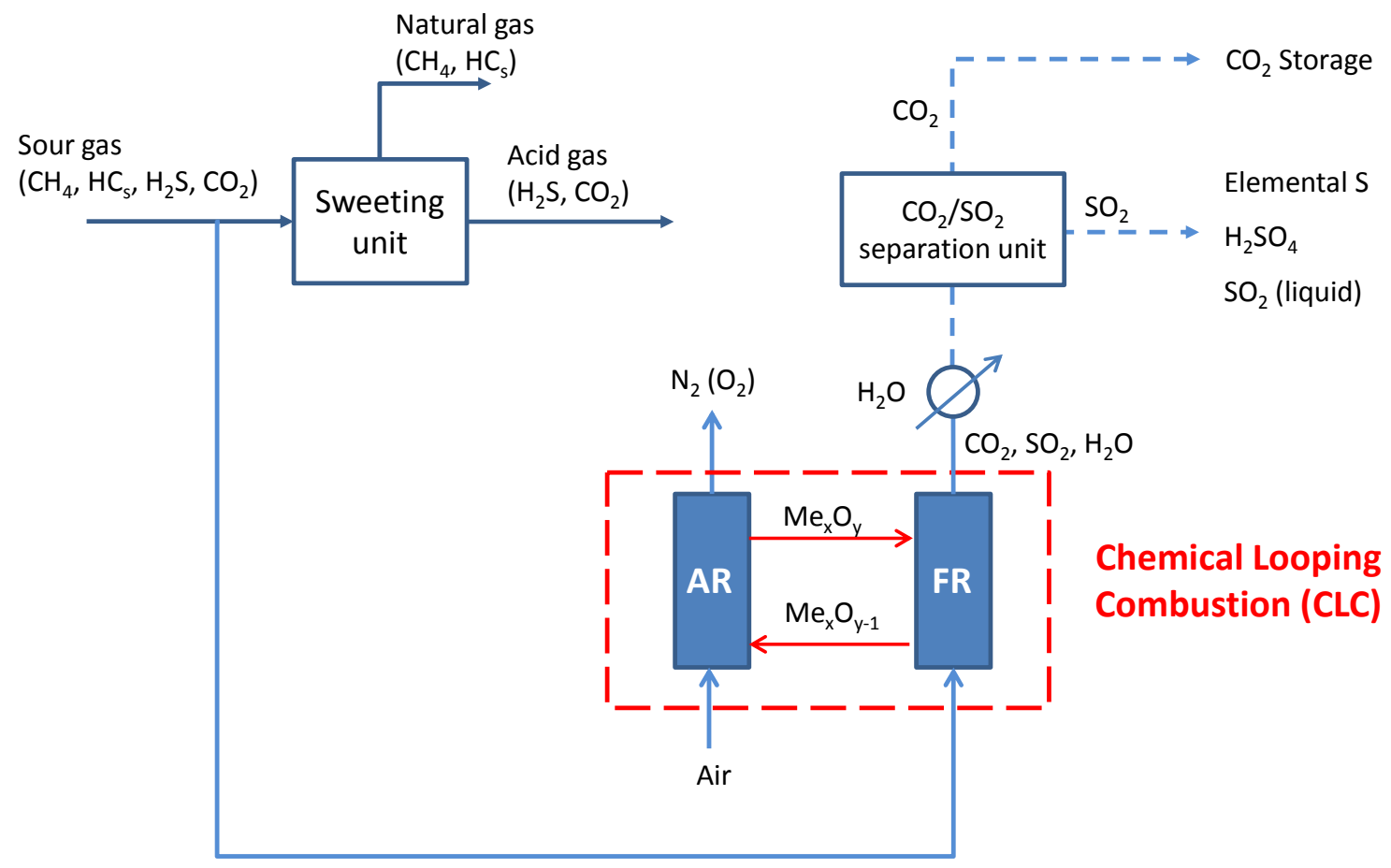

Figure 1. Scheme to deal with sour gases through Chemical Looping Combustion technology.

721

722 


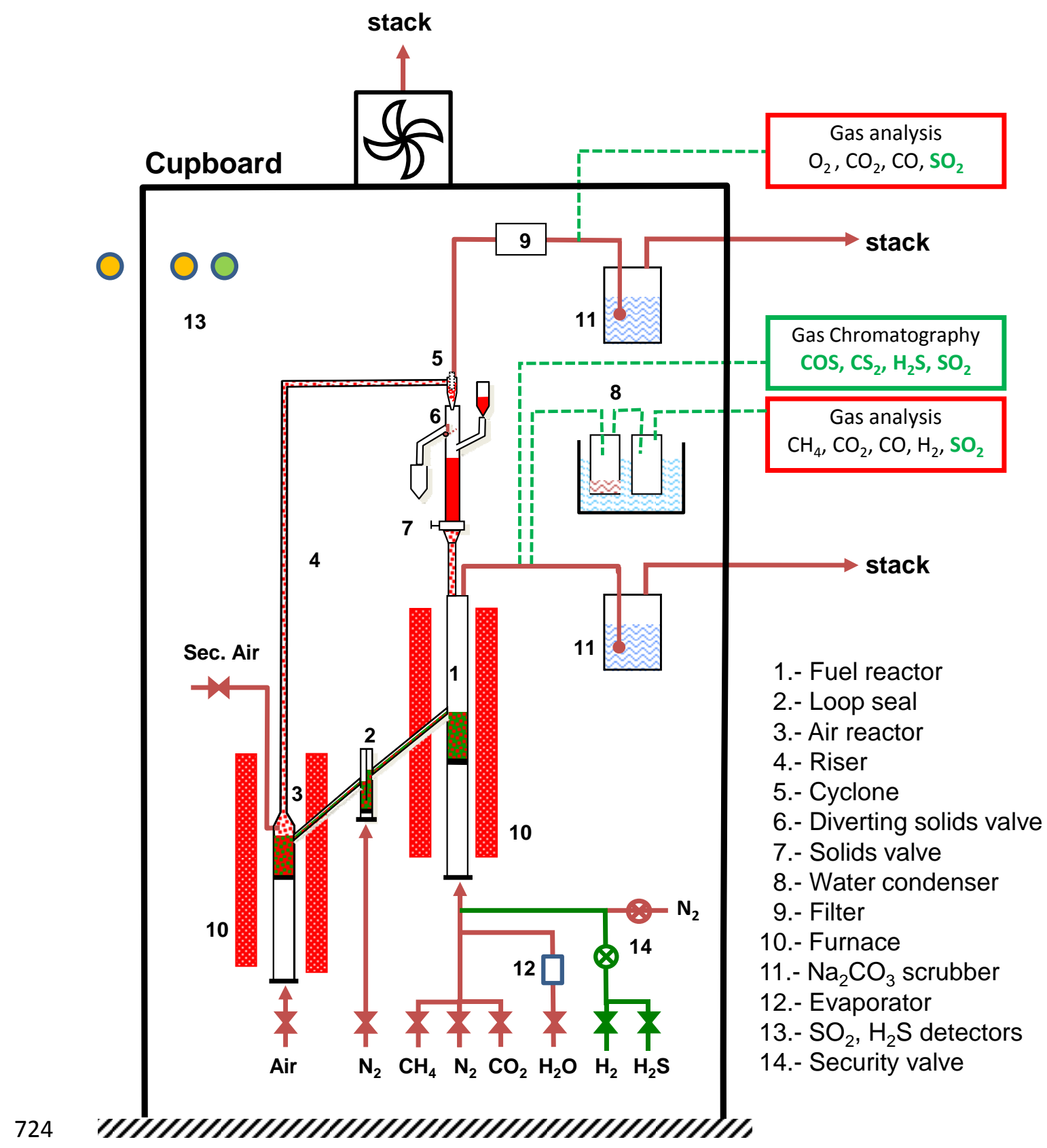

Figure 2. Scheme of the ICB-CSIC-g1 facility $\left(500 \mathrm{~W}_{\text {th }}\right)$ after modifications made for safe operation with high $\mathrm{H}_{2} \mathrm{~S}$ concentrations. 


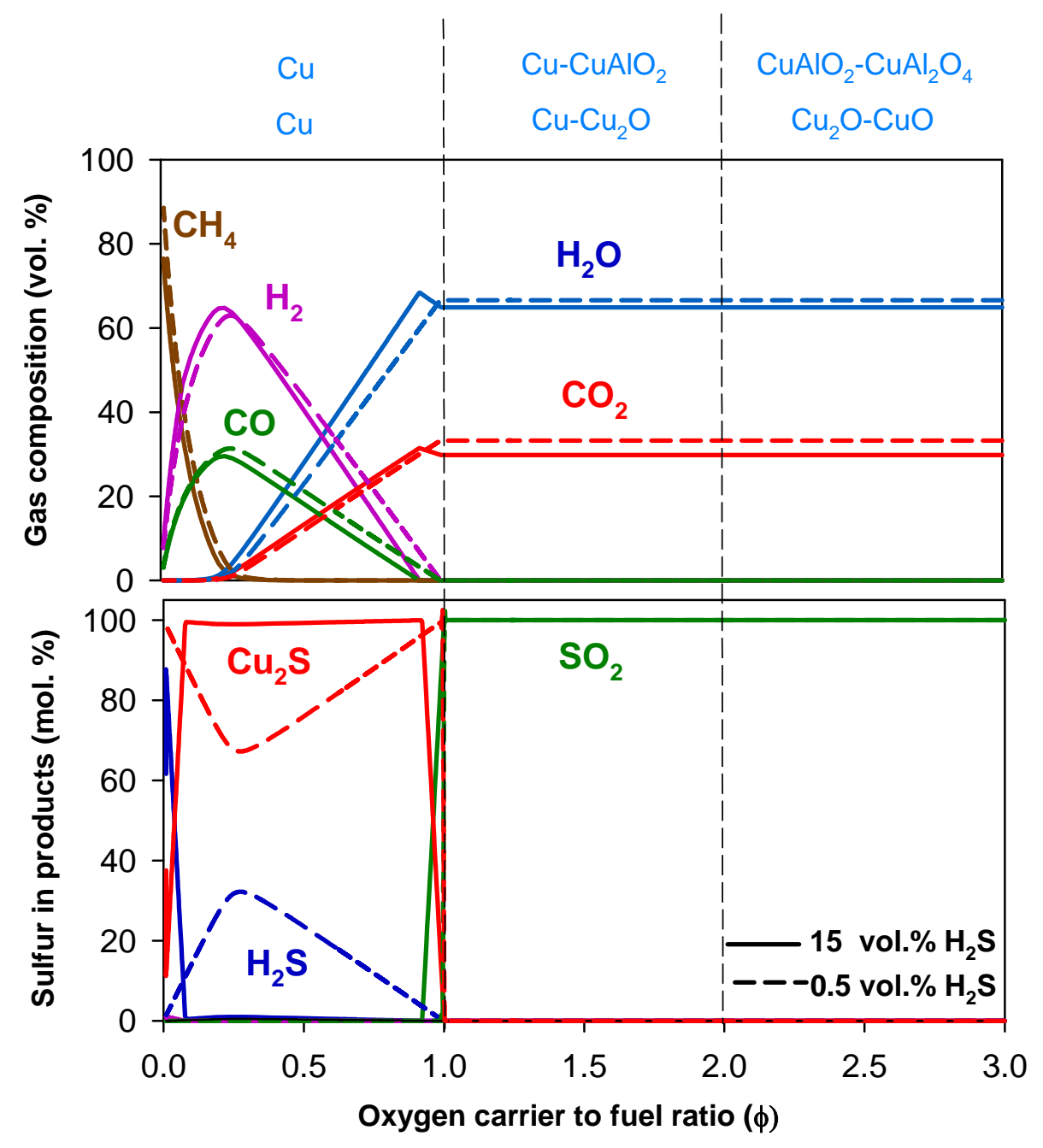

735

736

737 Figure 3. Thermodynamic calculations for the systems $\mathrm{CuO} /$ sour gas and $\mathrm{CuAl}_{2} \mathrm{O}_{4} /$ sour gas.

738 Sour gas 1 composition: 85 vol. $\% \mathrm{CH}_{4}-15$ vol.\% $\mathrm{H}_{2} \mathrm{~S}$. Sour gas 2 composition: 99.5 vol.\% $\mathrm{CH}_{4^{-}}$ 0.5 vol. $\% \mathrm{H}_{2} \mathrm{~S} . \mathrm{T}=1073 \mathrm{~K}$. 

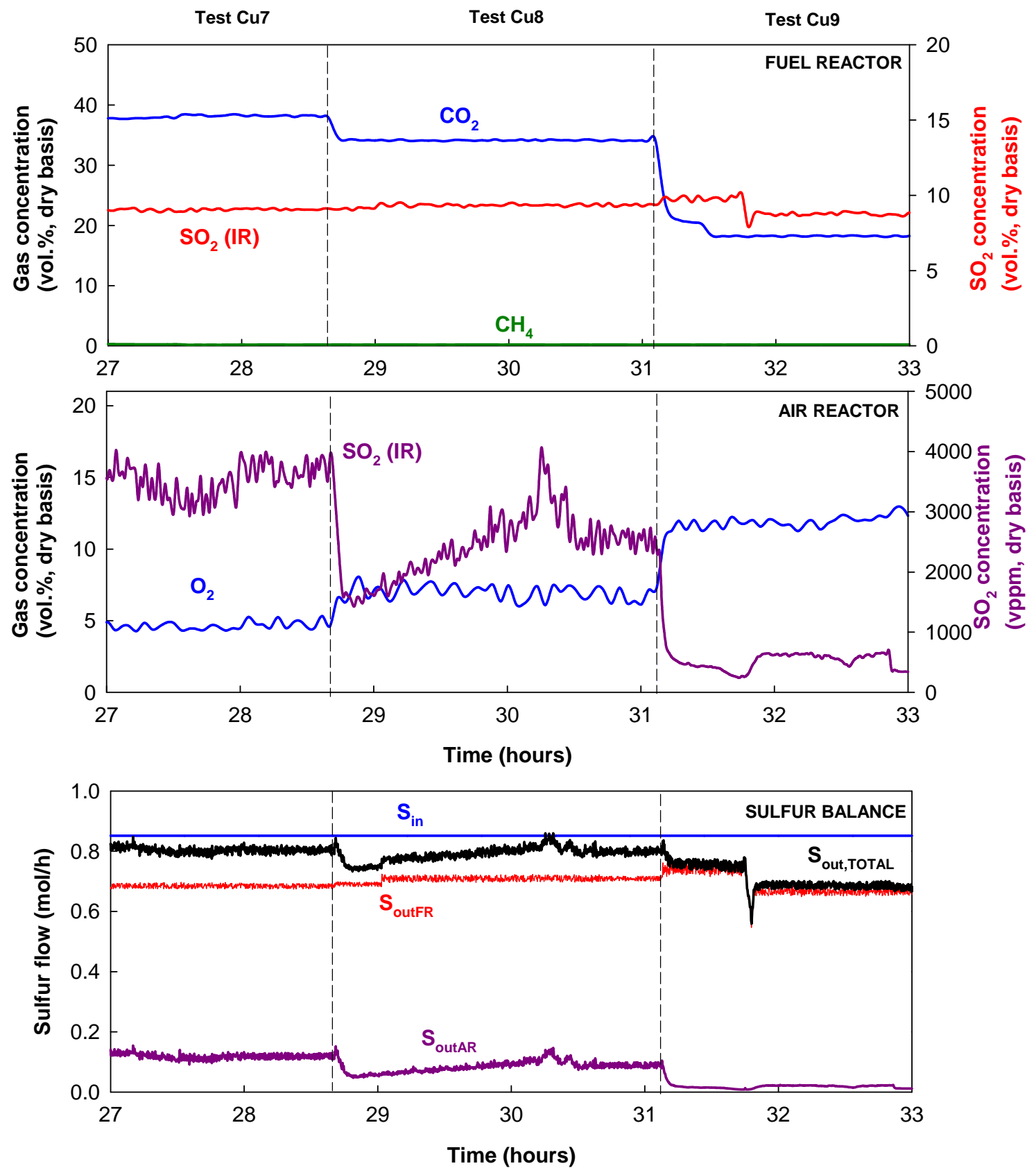

745 Figure 4. Gas composition at the outlet stream from the FR and AR, and sulfur balance corresponding to tests $\mathrm{Cu} 7-9$ with the $\mathrm{Cu} 14 \gamma \mathrm{Al}$ material. 


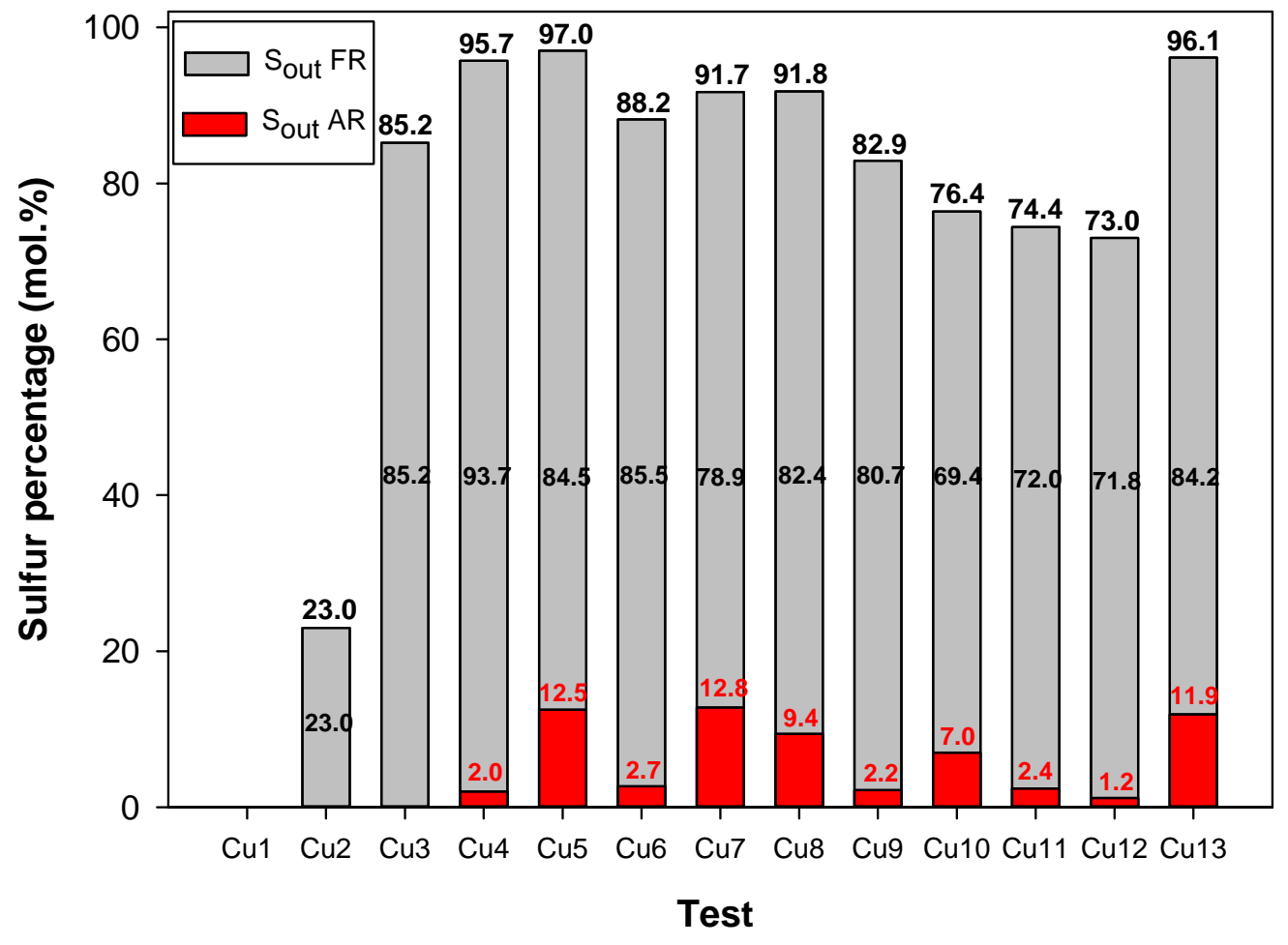

755 Figure 5. Sulfur mass balances for the combustion of sour gas with the $\mathrm{Cu}$-based oxygen carrier. Only gas emissions as $\mathrm{SO}_{2}$ in FR and AR are considered. 

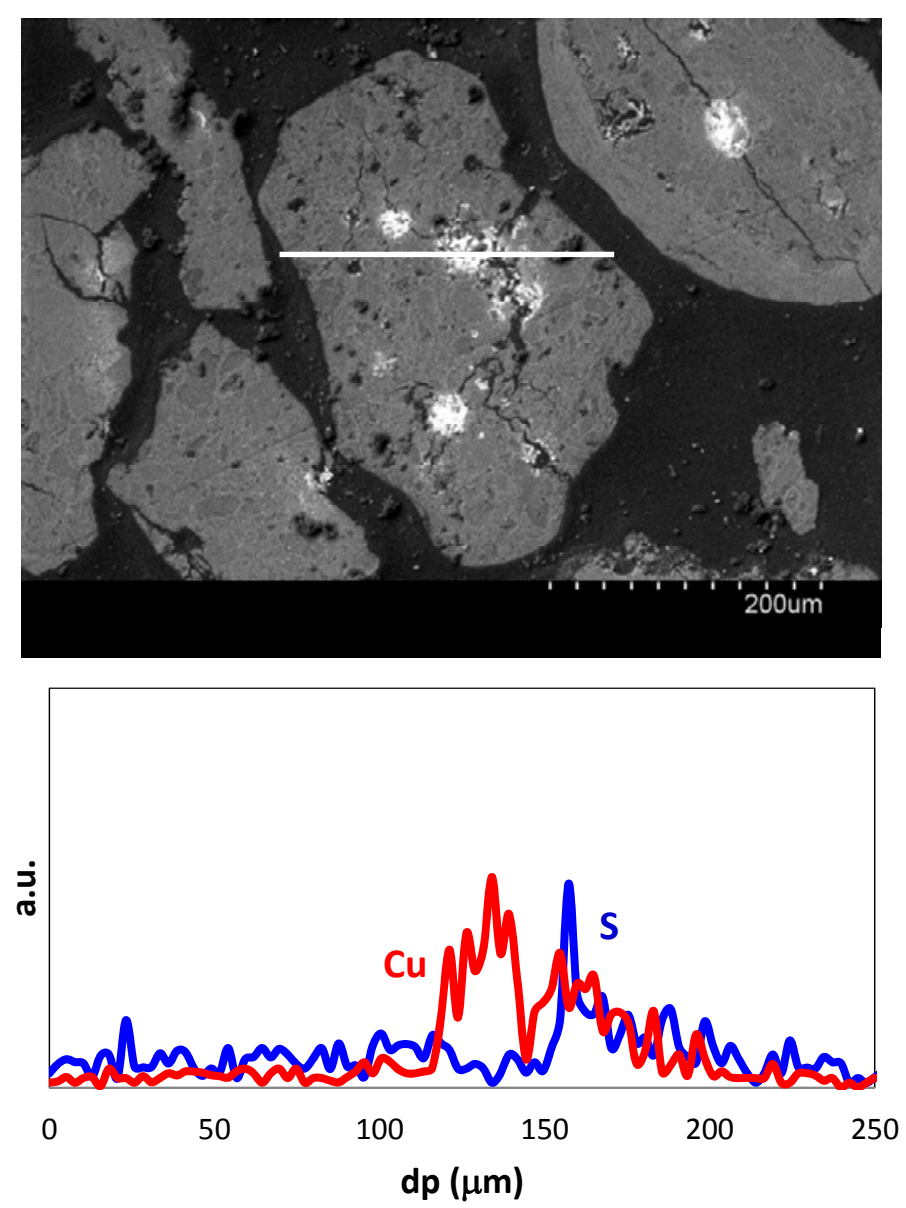

764

765 Figure 6. SEM-EDX image of a cross-section of a Cu14 $\gamma \mathrm{Al}$ oxygen carrier particle after $40 \mathrm{~h}$ of 766 sour gas combustion in the CLC unit.

767 


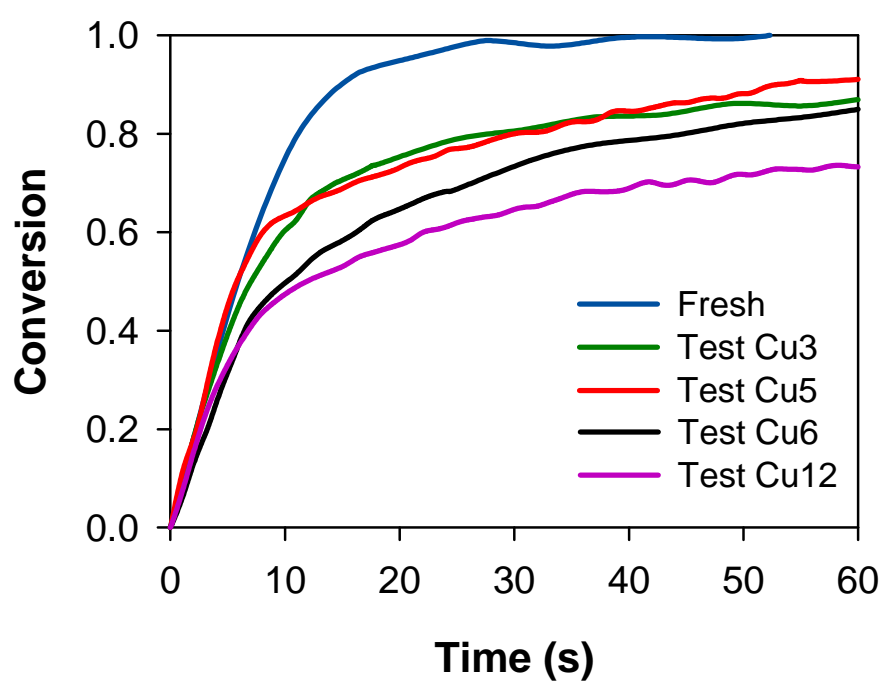

775

776 Figure 7. Reduction reactivity of the Cu14- $\gamma \mathrm{Al}$ material after different combustion tests with 777 sour gas. Reducing gas: 15 vol. $\% \mathrm{CH}_{4} . \mathrm{T}=1073 \mathrm{~K}$. 


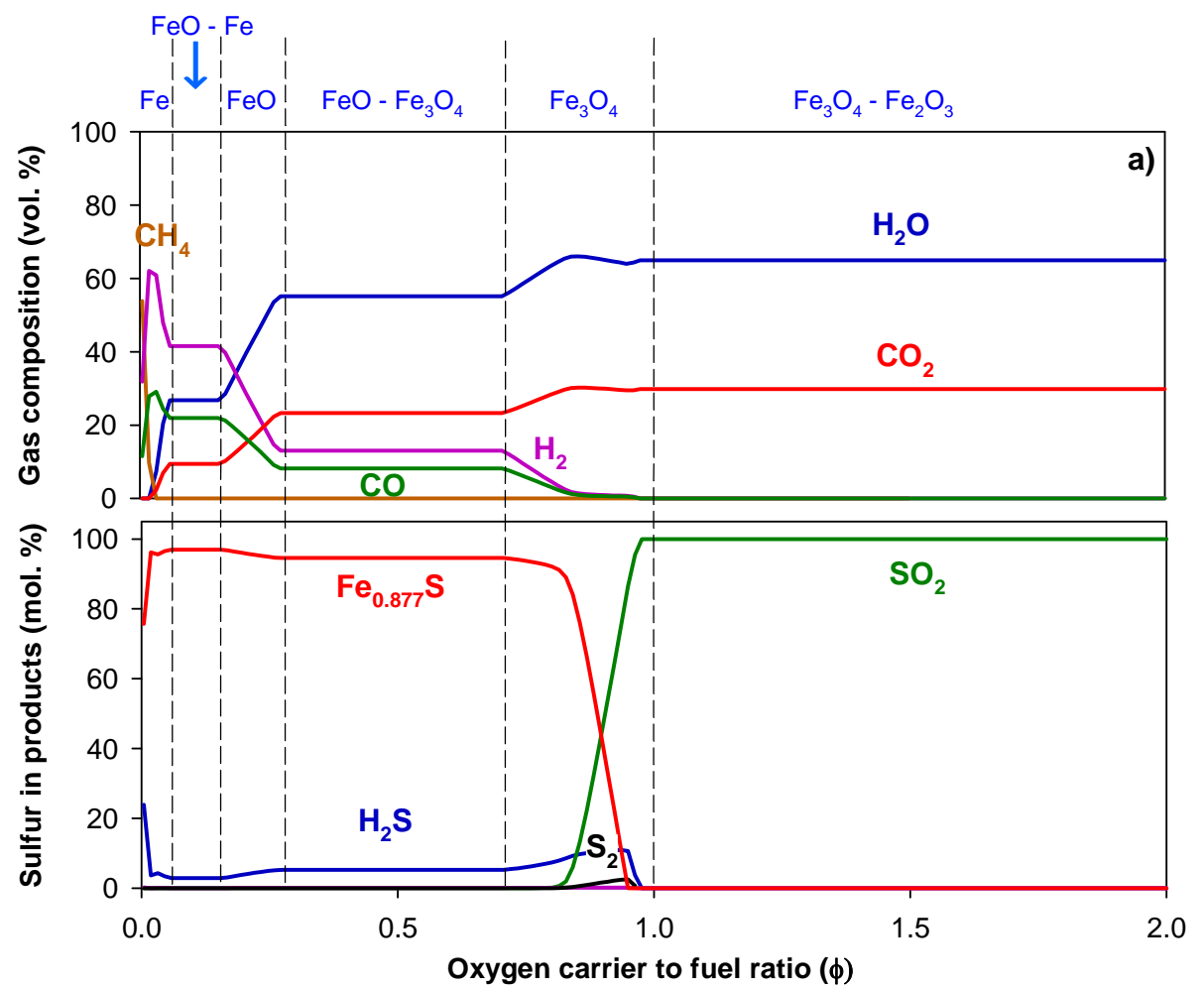

782

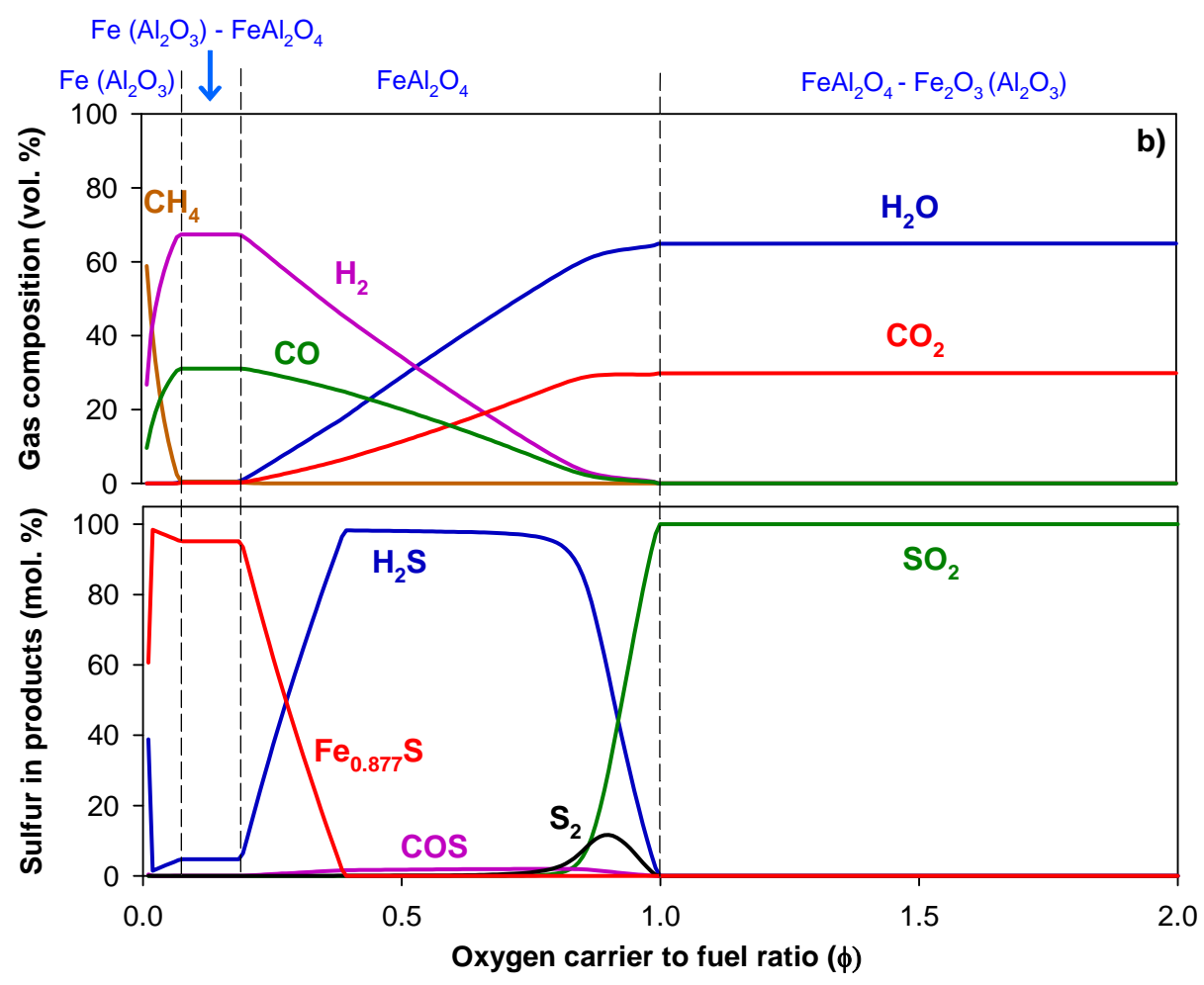

784 Figure 8. Thermodynamic calculations for the systems $\mathrm{Fe}_{2} \mathrm{O}_{3}-\mathrm{Fe}_{3} \mathrm{O}_{4} /$ sour gas (a) and $\mathrm{Fe}_{2} \mathrm{O}_{3}$

$785\left(\mathrm{Al}_{2} \mathrm{O}_{3}\right)-\mathrm{FeO} \cdot \mathrm{Al}_{2} \mathrm{O}_{3} /$ sour gas (b). Sour gas composition: 85 vol. $\% \mathrm{CH}_{4}-15$ vol. $\% \mathrm{H}_{2} \mathrm{~S} . \mathrm{T}=1223$ K. 

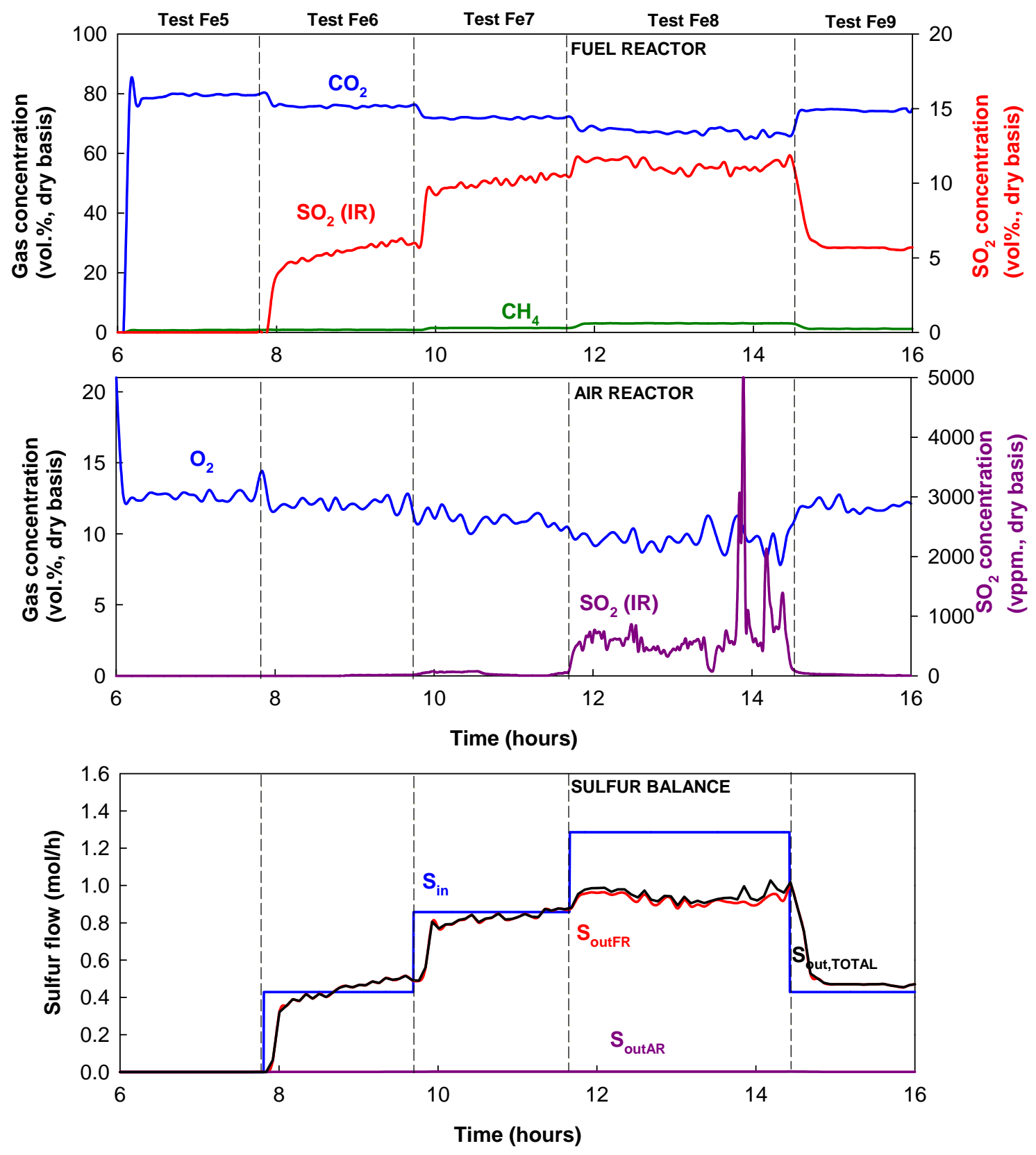

791

Figure 9. Gas composition at the outlet stream from the FR and AR, and sulfur balance corresponding to tests $\mathrm{Fe} 5-\mathrm{Fe} 9$ with the $\mathrm{Fe} 20 \gamma \mathrm{Al}$ oxygen carrier. 


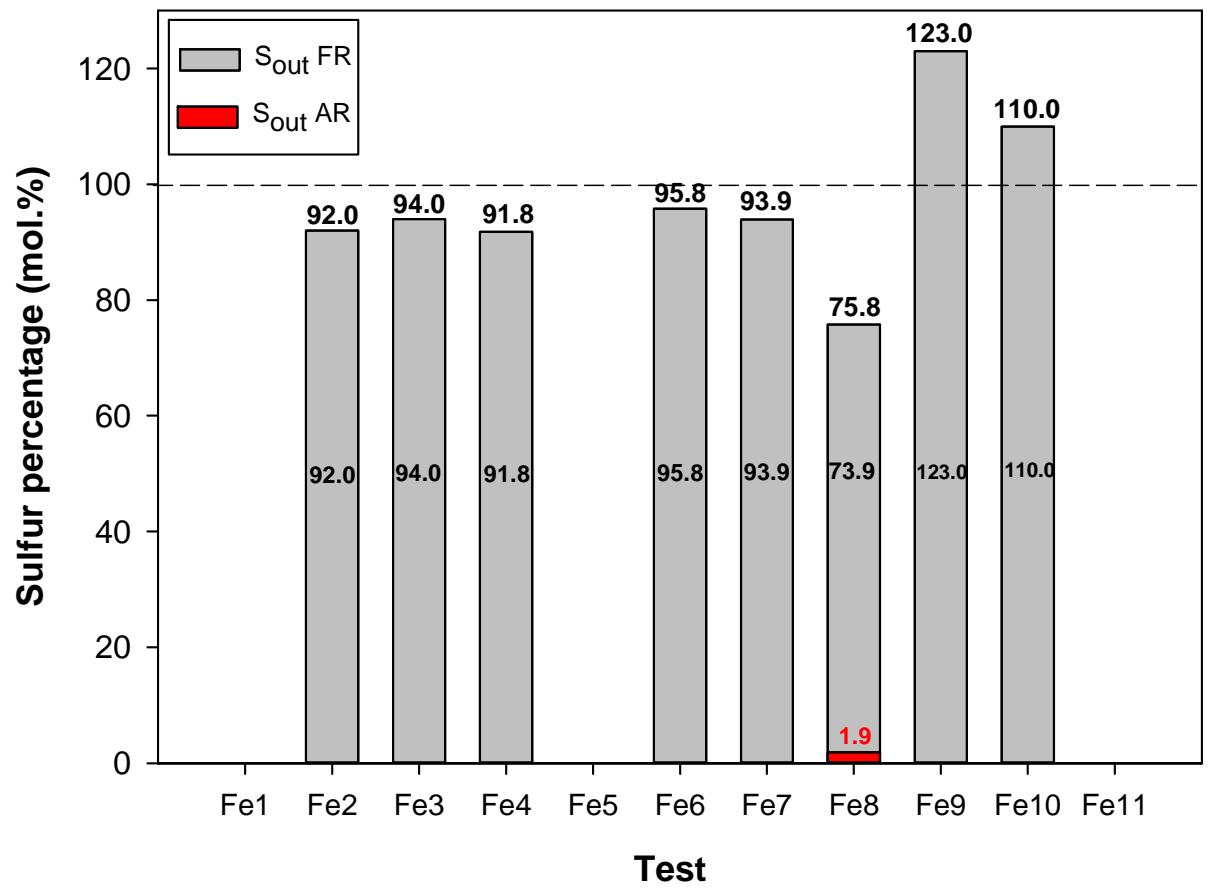

803

804 Figure 10. Sulfur mass balances for the combustion of sour gas with the Fe-based oxygen 805 carrier.

806 

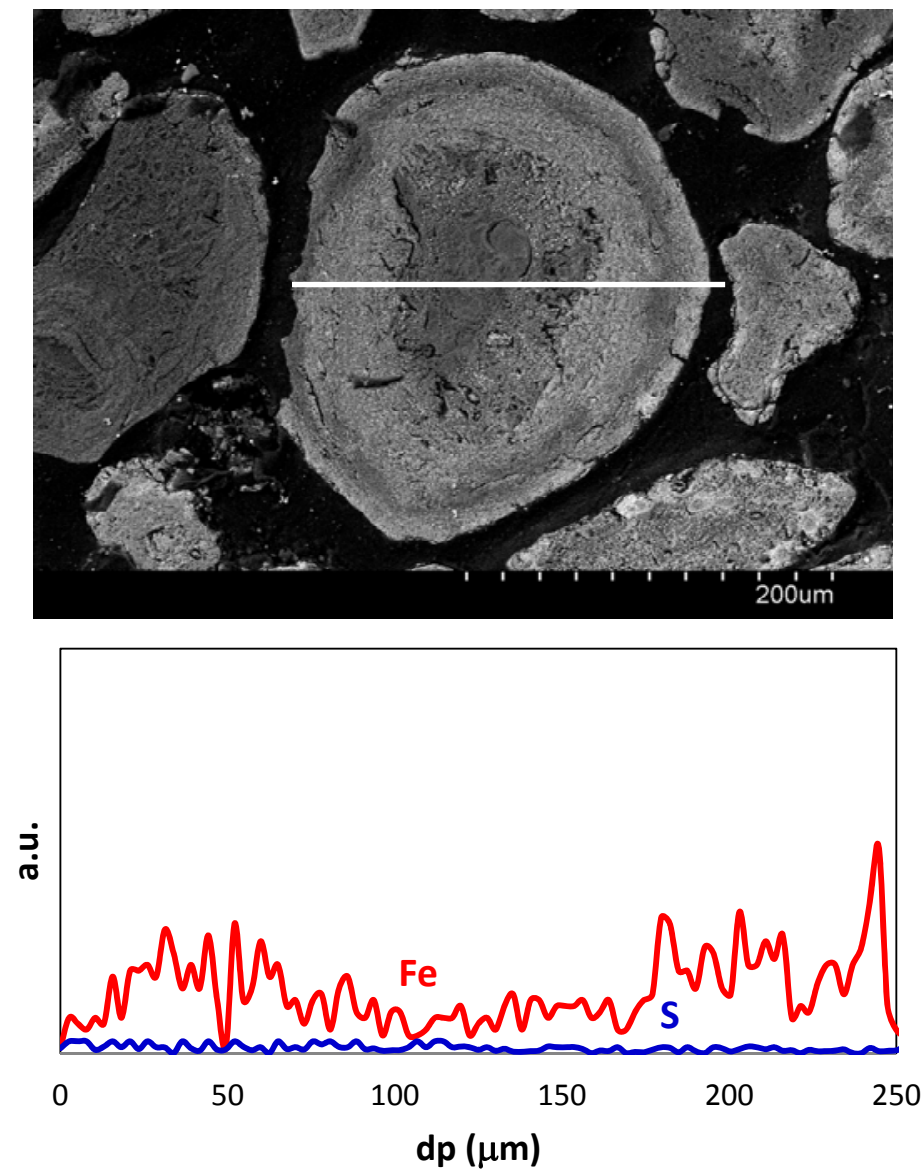

812

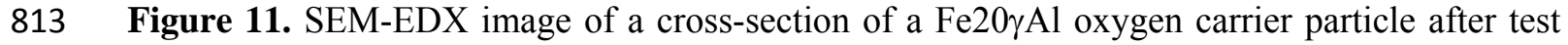
$814 \quad \mathrm{Fe} 8$ in the CLC unit. 


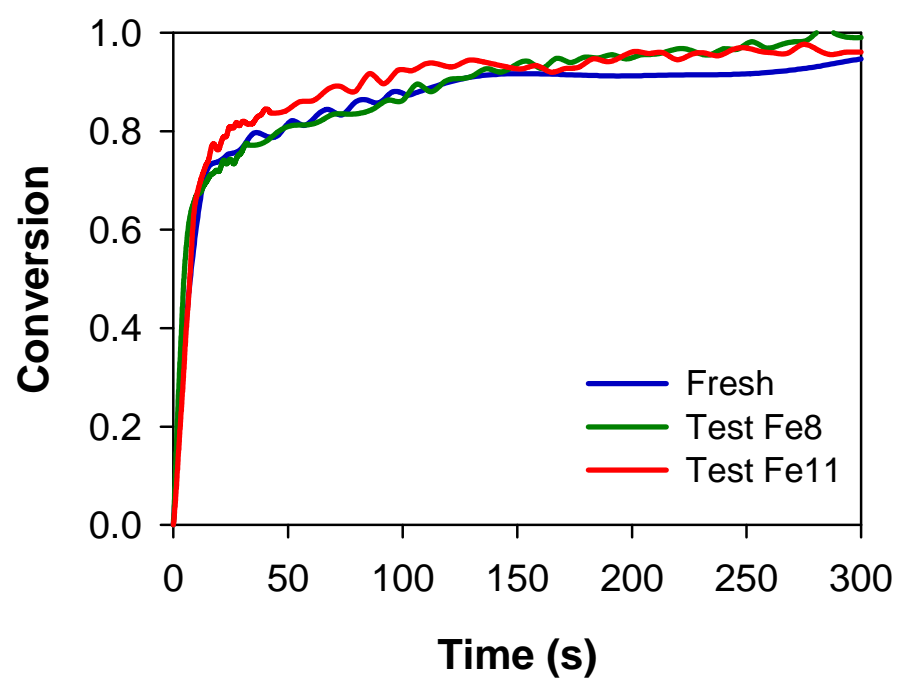

824

825 Figure 12. Reduction reactivity of the Fe20yAl oxygen carrier during the combustion tests with 826 sour gas. Reducing gas: 15 vol. $\% \mathrm{CH}_{4} . \mathrm{T}=1223 \mathrm{~K}$.

827

828 
830 Tables

831 Table 1. Combustion tests of sour gas with the $\mathrm{Cu}$-based oxygen carrier.

832 Table 2. Combustion tests of sour gas with the Fe-based oxygen carrier.

833 Table 3. Main characteristics of fresh and after-used particles of the Cu14- $\gamma \mathrm{Al}$ material.

834 Table 4. Main characteristics of fresh and after-used particles of the Fe20yAl oxygen carrier.

835

836 
843 Table 1. Combustion tests of sour gas with the $\mathrm{Cu}$-based oxygen carrier.

\begin{tabular}{|c|c|c|c|c|c|c|c|c|c|c|c|c|}
\hline \multirow[b]{2}{*}{ Test } & \multirow[b]{2}{*}{$\begin{array}{l}\mathrm{T}_{\mathrm{FR}} \\
(\mathrm{K})\end{array}$} & \multirow[b]{2}{*}{$\begin{array}{l}\mathrm{T}_{\mathrm{AR}} \\
(\mathrm{K})\end{array}$} & \multicolumn{5}{|c|}{ Gas composition (vol. \%) } & \multirow[b]{2}{*}{$\mathrm{CO}_{2}$} & \multirow[b]{2}{*}{$\begin{array}{c}\mathrm{f}_{\mathrm{s}} \\
(\mathrm{kg} / \mathrm{h})\end{array}$} & \multirow[b]{2}{*}{$\phi$} & \multirow[b]{2}{*}{$\begin{array}{l}\text { Time } \\
\text { (h) }\end{array}$} & \multirow[b]{2}{*}{$\begin{array}{l}\text { Accumulated } \\
\text { time (h) }\end{array}$} \\
\hline & & & $\mathrm{CH}_{4}$ & $\mathrm{H}_{2}$ & $\mathrm{H}_{2} \mathrm{O}$ & $\mathrm{H}_{2} \mathrm{~S}$ & $\mathrm{~N}_{2}$ & & & & & \\
\hline $\mathrm{Cu} 1$ & 1073 & 1123 & 30 & 5 & 10 & 0 & 55 & 0 & 14.7 & 2.4 & 2.0 & 2.0 \\
\hline $\mathrm{Cu} 2$ & 1073 & 1123 & 30 & 5 & 10 & 0.3 & 54.7 & 0 & 9.4 & 1.5 & 3.0 & 5.0 \\
\hline $\mathrm{Cu} 3$ & 1073 & 1123 & 30 & 5 & 10 & 1 & 54 & 0 & 9.4 & 1.4 & 4.0 & 9.0 \\
\hline $\mathrm{Cu} 4$ & 1073 & 1123 & 30 & 5 & 10 & 3 & 52 & 0 & 9.7 & 1.3 & 9.5 & 18.5 \\
\hline $\mathrm{Cu} 5$ & 1073 & 1123 & 30 & 5 & 10 & 5 & 50 & 0 & 9.5 & 1.3 & 5.0 & 23.5 \\
\hline $\mathrm{Cu} 6$ & 1073 & 1123 & 20 & 5 & 10 & 5 & 60 & 0 & 9.5 & 1.9 & 3.5 & 27.0 \\
\hline $\mathrm{Cu} 7$ & 1073 & 1123 & 30 & 5 & 10 & 10 & 45 & 0 & 9.2 & 1.3 & 1.5 & 28.5 \\
\hline $\mathrm{Cu} 8$ & 1073 & 1123 & 25 & 5 & 10 & 10 & 50 & 0 & 9.2 & 1.5 & 2.5 & 31.0 \\
\hline $\mathrm{Cu} 9$ & 1073 & 1123 & 15 & 5 & 10 & 10 & 60 & 0 & 9.2 & 2.5 & 2.0 & 33.0 \\
\hline $\mathrm{Cu} 10$ & 1073 & 1123 & 20 & 5 & 10 & 15 & 50 & 0 & 9.4 & 1.8 & 2.5 & 35.5 \\
\hline $\mathrm{Cu} 11$ & 1073 & 1123 & 15 & 5 & 10 & 15 & 55 & 0 & 9.4 & 2.4 & 2.5 & 38.0 \\
\hline $\mathrm{Cu} 12$ & 1073 & 1123 & 10 & 5 & 10 & 15 & 60 & 0 & 9.4 & 3.7 & 2.0 & 40.0 \\
\hline $\mathrm{Cu} 13^{\mathrm{a}}$ & 1073 & 1123 & 30 & 5 & 10 & 5 & 0 & 50 & 9.4 & 1.3 & 3.0 & 3.0 \\
\hline
\end{tabular}


848

849

850

851

852 Table 2. Combustion tests of sour gas with the Fe-based oxygen carrier.

\begin{tabular}{|c|c|c|c|c|c|c|c|c|c|c|c|c|}
\hline \multirow[b]{2}{*}{ Test } & \multirow[b]{2}{*}{$\begin{array}{l}\mathrm{T}_{\mathrm{FR}} \\
(\mathrm{K})\end{array}$} & \multirow[b]{2}{*}{$\begin{array}{l}\mathrm{T}_{\mathrm{AR}} \\
(\mathrm{K})\end{array}$} & \multicolumn{6}{|c|}{ Gas composition (vol. \%) } & \multirow[b]{2}{*}{$\begin{array}{c}\mathrm{f}_{\mathrm{s}} \\
(\mathrm{kg} / \mathrm{h})\end{array}$} & \multirow[b]{2}{*}{$\phi$} & \multirow[b]{2}{*}{$\begin{array}{l}\text { Time } \\
\text { (h) }\end{array}$} & \multirow[b]{2}{*}{$\begin{array}{l}\text { Accumulated } \\
\text { time (h) }\end{array}$} \\
\hline & & & $\mathrm{CH}_{4}$ & $\mathrm{H}_{2}$ & $\mathrm{H}_{2} \mathrm{O}$ & $\mathrm{H}_{2} \mathrm{~S}$ & $\mathrm{~N}_{2}$ & $\mathrm{CO}_{2}$ & & & & \\
\hline $\mathrm{Fe} 1$ & 1173 & 1223 & 10 & 5 & 20 & 0 & 0 & 65 & 14.0 & 4.4 & 1.5 & 1.5 \\
\hline $\mathrm{Fe} 2$ & 1173 & 1223 & 10 & 5 & 20 & 5 & 0 & 60 & 14.0 & 3.3 & 1.5 & 3.0 \\
\hline $\mathrm{Fe} 3$ & 1173 & 1223 & 10 & 5 & 20 & 10 & 0 & 55 & 14.0 & 2.6 & 2.0 & 5.0 \\
\hline $\mathrm{Fe} 4$ & 1173 & 1223 & 10 & 5 & 20 & 15 & 0 & 50 & 14.0 & 2.2 & 2.0 & 7.0 \\
\hline $\mathrm{Fe} 5$ & 1173 & 1223 & 20 & 5 & 20 & 0 & 0 & 55 & 13.0 & 2.1 & 2.0 & 9.0 \\
\hline Fe6 & 1173 & 1223 & 20 & 5 & 20 & 5 & 0 & 50 & 13.0 & 1.7 & 2.0 & 11.0 \\
\hline $\mathrm{Fe} 7$ & 1173 & 1223 & 20 & 5 & 20 & 10 & 0 & 45 & 13.0 & 1.5 & 2.0 & 13.0 \\
\hline $\mathrm{Fe} 8$ & 1173 & 1223 & 20 & 5 & 20 & 15 & 0 & 40 & 13.0 & 1.3 & 2.5 & 15.5 \\
\hline $\mathrm{Fe} 9$ & 1173 & 1223 & 20 & 5 & 20 & 5 & 0 & 50 & 13.0 & 1.7 & 1.5 & 17.0 \\
\hline $\mathrm{Fe} 10$ & 1173 & 1223 & 20 & 5 & 20 & 5 & 50 & 0 & 13.0 & 1.7 & 1.5 & 18.5 \\
\hline $\mathrm{Fe} 11$ & 1173 & 1223 & 10 & 5 & 20 & 0 & 65 & 0 & 13.0 & 3.9 & 1.5 & 20.0 \\
\hline
\end{tabular}

853 
Table 3. Main characteristics of fresh and after-used particles of the $\mathrm{Cu} 14-\gamma \mathrm{Al}$ material.

\begin{tabular}{|c|c|c|c|c|c|}
\hline Test & $\begin{array}{c}\mathrm{H}_{2} \mathrm{~S} \\
(\mathrm{vol} . \%)\end{array}$ & $\begin{array}{l}\text { Time } \\
\text { (h) }\end{array}$ & $\begin{array}{c}\mathrm{S}^{\mathrm{a}} \\
\text { (wt.\%) }\end{array}$ & $\begin{array}{l}\mathrm{Cu}_{2} \mathrm{~S}^{\mathrm{b}} \\
\text { (wt.\%) }\end{array}$ & XRD (AR samples) \\
\hline Fresh & & & & & $\gamma-\mathrm{Al}_{2} \mathrm{O}_{3}, \mathrm{CuAl}_{2} \mathrm{O}_{4}, \mathrm{CuO}$ \\
\hline $\mathrm{Cu} 1$ & 0 & 2.0 & & & \\
\hline $\mathrm{Cu} 2$ & 0.3 & 5.0 & 0.25 & 1.23 & $\gamma-\mathrm{Al}_{2} \mathrm{O}_{3}, \delta-\mathrm{Al}_{2} \mathrm{O}_{3}, \mathrm{CuAl}_{2} \mathrm{O}_{4}, \mathrm{CuO}$ \\
\hline $\mathrm{Cu} 3$ & 1 & 9.0 & & & \\
\hline $\mathrm{Cu} 4$ & 3 & 18.5 & 0.23 & 1.14 & $\gamma-\mathrm{Al}_{2} \mathrm{O}_{3}, \delta-\mathrm{Al}_{2} \mathrm{O}_{3}, \alpha-\mathrm{Al}_{2} \mathrm{O}_{3}, \mathrm{CuAl}_{2} \mathrm{O}_{4}, \mathrm{CuO}$ \\
\hline $\mathrm{Cu} 5$ & 5 & 23.5 & & & \\
\hline $\mathrm{Cu} 6$ & 5 & 27.0 & 0.33 & 1.63 & $\gamma-\mathrm{Al}_{2} \mathrm{O}_{3}, \delta-\mathrm{Al}_{2} \mathrm{O}_{3}, \alpha-\mathrm{Al}_{2} \mathrm{O}_{3}, \mathrm{CuAl}_{2} \mathrm{O}_{4}, \mathrm{CuO}$ \\
\hline $\mathrm{Cu} 7$ & 10 & 28.5 & & & \\
\hline $\mathrm{Cu} 8$ & 10 & 31.0 & & & \\
\hline $\mathrm{Cu} 9$ & 10 & 33.0 & 0.40 & 1.98 & $\gamma-\mathrm{Al}_{2} \mathrm{O}_{3}, \delta-\mathrm{Al}_{2} \mathrm{O}_{3}, \alpha-\mathrm{Al}_{2} \mathrm{O}_{3}, \mathrm{CuAl}_{2} \mathrm{O}_{4}, \mathrm{CuO}$ \\
\hline $\mathrm{Cu} 10$ & 15 & 35.5 & & & \\
\hline $\mathrm{Cu} 11$ & 15 & 38.0 & & & \\
\hline $\mathrm{Cu} 12$ & 15 & 40.0 & 0.38 & 1.88 & $\gamma-\mathrm{Al}_{2} \mathrm{O}_{3}, \delta-\mathrm{Al}_{2} \mathrm{O}_{3}, \alpha-\mathrm{Al}_{2} \mathrm{O}_{3}, \mathrm{CuAl}_{2} \mathrm{O}_{4}, \mathrm{CuO}$ \\
\hline
\end{tabular}

860

${ }^{\mathrm{a}}$ Determined by ultimate analysis

861

${ }^{\mathrm{b}}$ Calculated from a.

862 
Table 4. Main characteristics of fresh and after-used particles of the Fe20yAl oxygen carrier.

\begin{tabular}{|c|c|c|c|c|}
\hline \multirow[b]{2}{*}{ Test } & \multicolumn{2}{|c|}{ Gas composition (vol.\%) } & \multirow[b]{2}{*}{ S (wt. \%) ${ }^{a}$} & \multirow[b]{2}{*}{ XRD (AR samples) } \\
\hline & $\mathrm{CH}_{4}$ & $\mathrm{H}_{2} \mathrm{~S}$ & & \\
\hline Fresh & & & & $\alpha-\mathrm{Al}_{2} \mathrm{O}_{3}, \mathrm{Fe}_{2} \mathrm{O}_{3}$ \\
\hline $\mathrm{Fe} 1$ & 10 & 0 & & \\
\hline $\mathrm{Fe} 2$ & 10 & 5 & & \\
\hline $\mathrm{Fe} 3$ & 10 & 10 & & \\
\hline $\mathrm{Fe} 4$ & 10 & 15 & $0.00(0.00)$ & $\alpha-\mathrm{Al}_{2} \mathrm{O}_{3}, \mathrm{Fe}_{2} \mathrm{O}_{3}$ \\
\hline $\mathrm{Fe} 5$ & 20 & 0 & & \\
\hline Fe6 & 20 & 5 & & \\
\hline $\mathrm{Fe} 7$ & 20 & 10 & & \\
\hline $\mathrm{Fe} 8$ & 20 & 15 & $0.02(0.02)$ & $\alpha-\mathrm{Al}_{2} \mathrm{O}_{3}, \mathrm{Fe}_{2} \mathrm{O}_{3}$ \\
\hline $\mathrm{Fe} 9$ & 20 & 5 & & \\
\hline Fe10 & 20 & 5 & & \\
\hline Fe11 & 10 & 0 & $0.00(0.00)$ & $\alpha-\mathrm{Al}_{2} \mathrm{O}_{3}, \mathrm{Fe}_{2} \mathrm{O}_{3}$ \\
\hline
\end{tabular}

a. Determined by ultimate analysis. Data from FR in brackets. 